\title{
Checklist of Nemertean Genera and Species Published between 1995 and 2007
}

\author{
Hiroshi Kajihara ${ }^{1}$, Alexei V. Chernyshev ${ }^{2}$, Shi-Chun Sun ${ }^{3}$, \\ Per Sundberg ${ }^{4}$ and Frank B. Crandall ${ }^{5}$ \\ ${ }^{1}$ Faculty of Science, Hokkaido University, Sapporo, 060-0810 Japan \\ E-mail: kazi@mail.sci.hokudai.ac.jp \\ ${ }^{2}$ A. V. Zhirmunsky Institute of Marine Biology, Far East Division, \\ Russian Academy of Sciences, Vladivostok 690041, Russia \\ E-mail: tsher@bio.dvgu.ru \\ ${ }^{3}$ Marine Culture Research Laboratory, Ocean University of China, \\ Qingdao 266003, China \\ E-mail: sunsc@ouc.edu.cn \\ ${ }^{4}$ University of Gothenburg, Department of Zoology, \\ P.O. Box 463, SE-405 30 Göteborg, Sweden \\ E-mail:p.sundberg@zool.gu.se \\ ${ }^{5}$ Department of Invertebrate Zoology, National Museum of Natural History, \\ Smithsonian Institution, P.O. Box 37012, MRC 163, Washington, D.C. 20013-7012, USA \\ E-mail: CRANDALF@si.edu
}

(Received 20 March 2008; Accepted 22 August 2008)

Between the years 1995 and 2007, 48 nominal genera and 128 nominal species of nemerteans were established worldwide. During this period, taxonomic changes such as synonymization, alteration of affiliation to higher taxa, and resurrection of formerly invalid names were made for 26 genera and 69 species. The nominal genera and species established between 1995 and 2007, as well as the taxonomic changes made at the genus and species level, are listed here with their original citations. The type depositories for the nominal species established since 1995 are also mentioned. In total, 285 genera and 1275 species are currently recognized as valid in the phylum $\mathrm{Ne}$ mertea. Their distribution among higher taxa is as follows: Palaeonemertea (12 genera, 110 species), Pilidiophora (101, 450), Monostilifera (116, 570), Reptantia $(15,46)$, and Pelagica $(40,98)$, in addition to one species in a monotypic genus, the higher taxonomic affinities of which are uncertain. Two taxonomic and one nomenclatural changes are proposed herein: Sundbergia Gibson, 2002 and Tetramys Iwata, 1957 are tentatively transferred from the Palaeonemertea to the Pilidiophora, and Polydendrorhynchus Yin and Zeng, 1986 is substituted for Dendrorhynchus Yin and Zeng, 1985 to avoid homonymy with Dendrorhynchus Keilin, 1920 (Protozoa: Apicomplexa: Gregarinea); the latter results a new combination Polydendrorhynchus zhanjiangensis (Yin and Zeng, 1984).

Key Words: Nemertea, genus, species, checklist, type depositories, Sundbergia, Tetramys, Dendrorhynchus, Polydendrorhynchus zhanjiangensis comb. nov. 


\section{Introduction}

Gibson (1995) listed all the nemertean genera and species known to that date, recognizing 250 genera and 1149 species as valid. Here we present a list of genera and species established and taxonomically altered between 1995 and 2007, providing supplement and corrections to Gibson's (1995) checklist. The type depository of each listed nominal species is also mentioned. The genera and species are arranged alphabetically within the five unranked higher taxa recognized here, which are largely based on the traditional schemes provided by Gibson (1982a, b, 1994, 1995), Sundberg (1991), and Chernyshev (1995), in addition to Thollesson and Norenburg's (2003) molecular phylogenetic analysis within the phylum: Palaeonemertea; Pilidiophora (former Heteronemertea plus Hubrechtella and its allied genera); Monostilifera; Reptantia; Pelagica.

Throughout the text and tables, the International Commission on Zoological Nomenclature and the International Code of Zoological Nomenclature are referred to, respectively, as "ICZN" and the "Code". Cyrillic characters are romanized according to Barry (1997). Genus and species names currently recognized as valid are listed in bold-faced italics; those considered as invalid are in non-boldface italics. The following acronyms are used to indicate type depositories: GNHM, Göteborg Natural History Museum, Gothenburg, Sweden; IHBCAS, Institute of Hydrobiology, Chinese Academy of Sciences, Wuhan, China; LBM, Lake Biwa Museum, Kusatsu, Japan; LIVM, Liverpool Museum, Liverpool, UK; LZSEUR, Laboratoire de Zoologie et des Sciences de l'Environnement de l'Unité de Formation et de Recherche Sciences Exactes et Naturelles de l'Université de Reims Champagne-Ardenne, Rheims, France; MACN, Museo Argentino de Ciencias Naturales (Division Invertebrados), Buenos Aires, Argentina; MEUU, Museum of Evolution (catalogue number under "Nemertini"), Uppsala University, Uppsala, Sweden; MHNG, Muséum d'Histoire Naturelle de la Ville de Genève, Geneva, Switzerland; MMBI, Museum of A. V. Zirmunsky Institute of Marine Biology, Vladivostok, Russia; MNCN, Museo Nacional de Ciencias Naturales, Madrid, Spain; MNZTPT, Museum of New Zealand Te Papa Tongarewa, Wellington, New Zealand; MTQ, Museum of Tropical Queensland, Townsville, Australia; NHMW-EV, Naturhistorisches Museum in Wien, Evertebrata Varia, Vienna, Austria; NZOI, New Zealand Oceanographic Institute, National Institute of Water and Atmospheric Research, Wellington, New Zealand; OUCQ, Marine Culture Research Laboratory, Ocean University of China, Qingdao, China; QM, Queensland Museum, South Brisbane, Australia; SBMNH, Department of Invertebrate Zoology, Santa Barbara Museum of Natural History, Santa Barbara, USA; SMNH, Stockholm Museum of Natural History (Naturhistoriska Riksmuseet), Stockholm, Sweden; USNM, National Museum of Natural History, Smithsonian Institution, Washington DC, USA; WAM, Western Australian Museum, Perth, Australia; ZIHU, Hokkaido University Museum, Sapporo, Japan; ZIRAS, Zoological Institute, Russian Academy of Sciences, St. Petersburg, Russia; ZMFEU, Zoological Museum of the Far Eastern University, Vladivostok, Russia. 


\section{Results}

\section{Total taxa}

Forty-eight nominal genera and 128 nominal species of nemerteans have been established since 1995. Taking into account other taxonomic changes made after 1995 , the total numbers of nemertean genera and species currently recognized as valid are 285 and 1275, respectively. These are distributed among higher taxa as follows: Palaeonemertea (12 genera, 110 species), Pilidiophora (101, 450), Monostilifera $(116,570)$, Reptantia $(15,46)$, and Pelagica $(40,98)$, in addition to Arhynchonemertes axi Riser, 1988, an enigmatic species without a rhynchocoel and proboscis (Riser 1988), the phylogenetic position of which remains uncertain.

\section{Nemertean genera established since 1995}

PALAEONEMERTEA

Balionemertes Sundberg, Gibson and Olsson, 2003 (Sundberg et al. 2003: 283). Type species: Balionemertes australiensis Sundberg, Gibson and Olsson, 2003; fixed by monotypy.

Parahubrechtia Gibson and Sundberg, 1999 (Gibson and Sundberg 1999: 159). Type species: Parahubrechtia jillae Gibson and Sundberg, 1999; fixed by original designation.

Protubulanus Chernyshev, 1995 (Chernyshev 1995: 11). Type species: Carinella theeli Bergendal, 1902; fixed by original designation.

\section{PILIDIOPHORA}

Ammolineus Senz, 2001 (Senz 2001a: 36). Type species: Ammolineus gaimardi Senz, 2001; fixed by original designation.

Amorphonemertes Cantell, 1998 (Cantell 1998: 293). Type species: Amorphonemertes kubergensis Cantell, 1998; fixed by original designation.

Fragilonemertes Riser, 1998 (Riser 1998a: 149). Type species: Meckelia rosea Leidy, 1851; fixed by original designation.

Note: USNM \#170035 was designated as the neotype of Fragilonemertes rosea (Leidy, 1851) by Riser (1998a: 150).

Gastropion Moretto, 1998 (Moretto 1998: 215). Type species: Gastropion sanmatiensis Moretto, 1998; fixed by original designation.

Heteroenopleus Wern, 1998 (Wern 1998: 136). Type species: Heteroenopleus enigmaticus Wern, 1998; fixed by monotypy.

Heteronemertes Chernyshev, 1995 (Chernyshev 1995: 15). Type species: Cerebratulus longifissus Hubrecht, 1887; fixed by original designation.

Kohnia Sundberg and Gibson, 1995 (Sundberg and Gibson 1995: 104). Type species: Kohnia rottnestensis Sundberg and Gibson, 1995; fixed by original designation.

Kukumia Gibson and Sundberg, 2002 (Gibson and Sundberg 2002: 1791). Type species: Kukumia solomonensis Gibson and Sundberg, 2002; fixed by original designation.

Leucocephalonemertes Cantell, 1996 (Cantell 1996: 116). Type species: Meckelia aurantiaca Grube, 1855; fixed by monotypy.

Micconemertes Gibson, 1997 (Gibson 1997: 23). Type species: Micconemertes orientalis Gibson, 1997; fixed by original designation.

Myorhynchonemertes Senz, 1997 (Senz 1997a: 483). Type species: Meckelia striata 
Schmarda, 1859; fixed by original designation.

Nipponomicrura Chernyshev, 1995 (Chernyshev 1995: 15). Type species: Micrura uchidai Yamaoka, 1940; fixed by original designation.

Paracerebratulus Senz, 1997 (Senz 1997a: 451). Type species: Paracerebratulus adriaticus Senz, 1997; fixed by original designation.

Quasiutolineides Senz, 2001 (Senz 2001a: 22). Type species: Quasiutolineides mcintoshi Senz, 2001; fixed by original designation.

Sundbergia Gibson, 2002 (Gibson 2002: 15). Type species: Sundbergia albula Gibson, 2002; fixed by original designation.

Note: Originally classified in the Palaeonemertea, but here tentatively reassigned to the Pilidiophora, due to its morphological similarity to Hubrechtella.

Uricholemma Sundberg and Gibson, 1995 (Sundberg and Gibson 1995: 121). Type species: Uricholemma nigricans Sundberg and Gibson, 1995; fixed by original designation.

Utolineides Senz, 1997 (Senz 1997a: 477). Type species: Utolineides alba Senz, 1997; fixed by original designation.

Yinia Sun and Lu, 1998 (Sun and Lu 1998: 176). Type species: Yinia pratensis Sun and $\mathrm{Lu}, 1998$; fixed by original designation.

Note: This name is preoccupied by Yinia Li, 1994 (Insecta: Psocoptera); Sun and $\mathrm{Lu}$ (2008) proposed a replacement name Yininemertes to remedy this homonymy.

MONOSTILIFERA

Achoronemertes Crandall and Gibson, 1998 (Crandall and Gibson 1998: 174). Type species: Amphiporus scoresbyi Wheeler, 1934; fixed by monotypy.

Aenigmanemertes Sundberg and Gibson, 1995 (Sundberg and Gibson 1995: 125). Type species: Aenigmanemertes norenburgi Sundberg and Gibson, 1995; fixed by original designation.

Crybelonemertes Sundberg and Gibson, 1995 (Sundberg and Gibson 1995: 131). Type species: Crybelonemertes arenicola Sundberg and Gibson, 1995; fixed by original designation.

Cyanonemertes Iwata, 2007 (Iwata 2007: 198). Type species: Cyanonemertes elegans Iwata, 2007; fixed by original designation.

Diopsonemertes Kajihara, Gibson and Mawatari, 2001 (Kajihara et al. 2001: 187). Type species: Diopsonemertes acanthocephala Kajihara, Gibson and Mawatari, 2001; fixed by original designation.

Frontonemertes Iwata, 2006 (Iwata 2006: 874). Type species: Frontonemertes serpentina Iwata, 2006; fixed by original designation.

Furugelmina Chernyshev, 1998 (Chernyshev 1998a: 401). Type species: $\boldsymbol{F} \boldsymbol{u}$ rugelmina heteromusculosa Chernyshev, 1998; fixed by original designation.

Heilogonemertes Gibson, 2002 (Gibson 2002: 68). Type species: Heilogonemertes cooki Gibson, 2002; fixed by original designation.

Kirsteueriella Chernyshev, 2002 (Chernyshev 2002a: 915). Type species: Paranemertes biocellata Coe, 1944; fixed by original designation.

Limnemertes Gibson and Wang, 2002 (Gibson and Wang 2002: 186). Type species: Limnemertes poyangensis Gibson and Wang, 2002; fixed by original designation.

Noteonemertes Gibson, 2002 (Gibson 2002: 48). Type species: Noteonemertes novaezealandiae Gibson, 2002; fixed by original designation. 
Ovicides Shields, 2001 (Shields 2001: 305). Type species: Ovicides julieae Shields, 2001; fixed by monotypy.

Parischyronemertes Gibson, 2002 (Gibson 2002: 54). Type species: Parischyronemertes mathesonensis Gibson, 2002; fixed by original designation.

Potamostoma Kajihara, Gibson and Mawatari, 2003 (Kajihara et al. 2003: 492). Type species: Potamostoma shizunaiense Kajihara, Gibson and Mawatari, 2003; fixed by original designation.

Protetrastemma Chernyshev, 2004 (Chernyshev 2004a: 151). Type species: Tetrastemma viride Kulikova, 1989; fixed by original designation.

Pseudotetrastemma Sun, 1993 (Sun 1993: 1306). Type species: Pseudotetrastemma qingdaoense Sun, 1993; fixed by original designation.

Note: Omitted in Gibson's (1995) checklist; the specific epithet was originally spelled in the masculine/feminine gender as "qingdaoensis".

Quasitetrastemma Chernyshev, 2004 (Chernyshev 2004a: 152). Type species: Tetrastemma nigrifrons Coe, 1904; fixed by original designation.

Quoyianemertes Senz, 2001 (Senz 2001a: 69). Type species: Quoyianemertes girardi Senz, 2001; fixed by original designation.

Sanjuannemertes Iwata, 2006 (Iwata 2006: 904). Type species: Sanjuannemertes willowsi Iwata, 2006; fixed by original designation.

Satellitenemertes Iwata, 2006 (Iwata 2006: 887). Type species: Satellitenemertes satellitensis Iwata, 2006; fixed by original designation.

Tetraneuronemertes Sundberg, Gibson and Strand, 2007 (Sundberg et al. 2007: 2293). Type species: Tetraneuronemertes lovgreni Sundberg, Gibson and Strand, 2007; fixed by original designation.

Thallassionemertes Gibson and Sundberg, 2001 (Gibson and Sundberg 2001: 1262). Type species: Thallassionemertes leucocephala Gibson and Sundberg, 2001; fixed by original designation.

Thermanemertes Rogers, Gibson and Tunnicliffe, 1996 (Rogers et al. 1996: 1583). Type species: Thermanemertes valens Rogers, Gibson and Tunnicliffe, 1996; fixed by original designation.

Typhloerstedia Chernyshev, 1999 (Chernyshev 1999a: 946). Type species: Typhloerstedia anadonae Chernyshev, 1999; fixed by original designation.

Note: A new name for Oerstedia vittata Hubrecht, 1879 sensu Anadon and Bitar (1992: 383).

Verrillianemertes Senz, 2001 (Senz 2001a: 61). Type species: Verrillianemertes rathkei Senz, 2001; fixed by original designation.

Vulcanonemertes Gibson and Strand, 2002 (Gibson and Strand 2002: 2). Type species: Vulcanonemertes rangitotoensis Gibson and Strand, 2002; fixed by original designation.

REPTANTIA

Kameginemertes Iwata, 1998 (Iwata 1998: 199). Type species: Amphiporus parmiornatus Iwata, 1957; fixed by original designation.

Nemertean species established since 1995 and their type depositories PALAEONEMERTEA

Balionemertes australiensis Sundberg, Gibson and Olsson, 2003 (Sundberg et al. 2003: 285). Holotype: MTQ G20021.

Callinera blanchardi Senz, 2000 (Senz 2000: 333). Holotype: NHMW-EV 4019. 
Callinera bergendali Gibson and Sundberg, 1999 (Gibson and Sundberg 1999: 165). Holotype: SMNH 4891.

Callinera emiliae Kajihara, 2007 (Kajihara 2007a: 40). Holotype: ZIHU 3187.

Callinera nishikawai Kajihara, 2006 (Kajihara 2006: 17). Holotype: ZIHU 3133.

Callinera quatrefagesi Senz, 2000 (Senz 2000: 339). Holotype: NHMW-EV 4012.

Callinera zhirmunskyi Chernyshev, 2002 (Chernyshev 2002b: 132). Holotype: ZMFEU IX-18165.

Carinina johnstoni Senz, 2000 (Senz 2000: 324). Holotype: NHMW-EV 4000.

Carinina plecta Kajihara, 2006 (Kajihara 2006: 5). Holotype: ZIHU 3123.

Carinina sinensis Gibson and Sundberg, 1999 (Gibson and Sundberg 1999: 171). Holotype: SMNH 4892.

Carinesta dellechiajei Senz, 2000 (Senz 2000: 328). Holotype: NHMW-EV 4004.

Carinoma renieri Senz, 2000 (Senz 2000: 346). Holotype: NHMW-EV 4030.

Carinoma uschakovi Chernyshev, 1999 (Chernyshev 1999b: 1276). Holotype: ZIRAS no. 2.

Cephalothrix gaimardi (Senz, 2000) (Senz 2000: 352). Holotype: NHMW-EV 4033. Note: Originally described as Cephalotrichella gaimardi Senz, 2000, herein listed under Cephalothrix Örsted, 1843 as the result of Sundberg et al.'s (2003) synonymization of Cephalotrichella Wijnhoff, 1913 with Cephalothrix.

Cephalothrix kefersteini Senz, 2000 (Senz 2000: 358). Holotype: NHMW-EV 4040.

Cephalothrix queenslandica Sundberg, Gibson and Olsson, 2003 (Sundberg et al. 2003: 292). Holotype: MTQ G20022.

Parahubrechtia jillae Gibson and Sundberg, 1999 (Gibson and Sundberg 1999: 159). Holotype: SMNH 4890.

Tubulanus hylbomi Gibson and Sundberg, 1999 (Gibson and Sundberg 1999: 178). Holotype: SMNH 4893.

Tubulanus longivasculus Gibson and Sundberg, 1999 (Gibson and Sundberg 1999: 186). Holotype: SMNH 4894.

Tubulanus lutescens Cantell, 2001 (Cantell 2001: 214). Holotype: MEUU 13.

Tubulanus riceae Ritger and Norenburg, 2006 (Ritger and Norenburg 2006: 933). Holotype: USNM 1083007.

Tubulanus roretzi Senz, 1997 (Senz 1997a: 424). Holotype: NHMW-EV 1886.

PILIDIOPHORA

Ammolineus gaimardi Senz, 2001 (Senz 2001a: 37). Holotype: NHMW-EV 4138 (ZA 14).

Amorphonemertes kubergensis Cantell, 1998 (Cantell 1998: 293). Holotype: MEUU 9.

Baseodiscus jonasii Strand, Hjelmgren and Sundberg, 2005 (Strand et al. 2005: 3792). Holotype: GNHM 78.

Cerebratulus aracaensis Senz, 1997 (Senz 1997a: 437). Holotype: NHMW-EV 16712/1564.

Gastropion sanmatiensis Moretto, 1998 (Moretto 1998: 216). Holotype: MACN 33886.

Heteroenopleus enigmaticus Wern, 1998 (Wern 1998: 137). Holotype: USNM 174075.

Hubrechtella alba Gibson, 1997 (Gibson 1997: 11). Holotype: LIVM 1996.26.1-22. Note: Originally classified in the Palaeonemertea, but removed to the Pilidiophora by Thollesson and Norenburg (2003).

Hubrechtella ehrenbergi Senz, 2000 (Senz 2000: 364). Holotype: NHMW-EV 4087. 
Note: Originally classified in the Palaeonemertea, but removed to the Pilidiophora by Thollesson and Norenburg (2003).

Hubrechtella juliae Chernyshev, 2003 (Chernyshev 2003a: 368). Holotype: ZMFEU no. IX N-158/19947.

Note: Originally classified in the Palaeonemertea, but removed to the Pilidiophora by Thollesson and Norenburg (2003).

Hubrechtella kimuraorum Kajihara, 2006 (Kajihara 2006: 37). Holotype: ZIHU 3127.

Note: Originally classified in the Palaeonemertea, but had been removed to the Pilidiophora by Thollesson and Norenburg (2003).

Hubrechtella sinimarina Gibson and Sundberg, 1999 (Gibson and Sundberg 1999: 153). Holotype: SMNH 4889.

Note: Specific epithet originally spelled in the masculine gender, as "sinimarinus"; originally classified in the Palaeonemertea, but removed to the Pilidiophora by Thollesson and Norenburg (2003).

Kohnia rottnestensis Sundberg and Gibson, 1995 (Sundberg and Gibson 1995: 104). Holotype: WAM 9-95.

Kukumia solomonensis Gibson and Sundberg, 2002 (Gibson and Sundberg 2002: 1792). Holotype: MTQ G20020.

Lineus bergendali Senz, 1996 (Senz 1996a: 198). Holotype: NHMW-EV 16708/3537.

Lineus bioculatus Sundberg and Gibson, 1995 (Sundberg and Gibson 1995: 108). Holotype: WAM 10-95.

Lineus gilviceps Sundberg and Gibson, 1995 (Sundberg and Gibson 1995: 112). Holotype: WAM 12-95.

Lineus fischeri Senz, 1997 (Senz 1997a: 470). Holotype: NHMW-EV 5209/3583.

Lineus frauenfeldi Senz, 1997 (Senz 1997a: 458). Holotype: NHMW-EV 3576.

Lineus nipponensis Senz, 2001 (Senz 2001b: 5). Holotype: NHMW-EV 17026/3990.

Lineus schultzei Senz, 2001 (Senz 2001a: 35). Holotype: NHMW-EV 4215 (ZA 11).

Lineus sowerbyi Senz, 2001 (Senz 2001a: 27). Holotype: NHMW-EV 4188 (ZA 03).

Micconemertes orientalis Gibson, 1997 (Gibson 1997: 23). Holotype: LIVM 1996.26.122-128.

Micrura achrostocephala Gibson, 1997 (Gibson 1997: 18). Holotype: LIVM 1996.26.50-93.

Micrura callima Sundberg and Gibson, 1995 (Sundberg and Gibson 1995: 116). Holotype: WAM 15-95.

Micrura chlorapardalis Schwartz and Norenburg, 2005 (Schwartz and Norenburg 2005: 538). Holotype: USNM 1081561.

Micrura ignea Schwartz and Norenburg, 2005 (Schwartz and Norenburg 2005: 540). Holotype: USNM 1081564.

Micrura rubramaculosa Schwartz and Norenburg, 2005 (Schwartz and Norenburg 2005: 530). Holotype: USNM 1081567.

Oxypolella banyulensis Cantell, 2005 (Cantell 2005: 124). Holotype: MEUU 14.

Paracerebratulus adriaticus Senz, 1997 (Senz 1997a: 451). Holotype: NHMW-EV $16640 / 3267$.

Quasiutolineides mcintoshi Senz, 2001 (Senz 2001a: 22). Holotype: NHMW-EV 4142 (UA 09).

Ramphogordius bicolor (Vernet, 1997) (Vernet 1997: 150). Holotype: LZSEUR sine numero. 
Note: Specific epithet originally combined with Myoisophagos Riser, 1994, which, however, is a junior synonym of Ramphogordius (Riser 1998a: 154).

Sundbergia albula Gibson, 2002 (Gibson 2002: 15). Holotype: NZOI H-772.

Note: Originally classified in the Palaeonemertea, but here tentatively treated as belonging to the Pilidiophora, due to its morphological similarity to Hubrechtella.

Uricholemma nigricans Sundberg and Gibson, 1995 (Sundberg and Gibson 1995: 121). Holotype: WAM 19-95.

Utolineides alba Senz, 1997 (Senz 1997b: 478). Holotype: NHMW-EV 3269.

Utolineides kenneli Senz, 2001 (Senz 2001a: 42). Holotype: NHMW-EV 4140 (ZI 02).

Valencinina hubrechti Senz, 2001 (Senz 2001a: 14). Holotype: NHMW-EV 4135 (UA 03).

Valencinura bergendali Senz, 1996 (Senz 1996b: 30). Holotype: NHMW-EV 16708/3537.

Yinia pratensis Sun and Lu, 1998 (Sun and Lu 1998: 176). Holotype: OUCQ DH005A. Note: The generic name Yinia Sun and Lu, 1998 was preoccupied by Yinia Li, 1994; now Yininemertes pratensis (Sun and Lu, 1998) (see Sun and Lu 2008).

MONOSTILIFERA

Aenigmanemertes norenburgi Sundberg and Gibson, 1995 (Sundberg and Gibson 1995: 125). Holotype: WAM 21-95.

Amphiporus microocelli (Sun, 1995) (Sun 1995a: 279). Holotype: OUCQ DH101. Note: Originally described as Psammamphiporus microocelli Sun, 1995, but Psammamphiporus Gibson, 1981 was synonymized with Amphiporus Ehrenberg, 1831 by Chernyshev (1998a: 398).

Amphiporus mortonmilleri Gibson, 2002 (Gibson 2002: 34). Holotype: NZOI H-785.

Amphiporus nadtochiae Chernyshev, 1998 (Chernyshev 1998a: 398). Holotype: ZMFEU 9/N-93.

Antarctonemertes varvarae Chernyshev, 1999 (Chernyshev 1999a: 942). Holotype: ZMFEU no. An-v 1.

Arctonemertes ussuriensis Chernyshev, 1998 (Chernyshev 1998a: 399). Holotype: ZMFEU no. 9/N-94.

Carcinonemertes caissarum Santos, Norenburg and Bueno, 2006 (Santos et al. 2006: 921). Holotype: MZUSP 003.

Note: The specific epithet is a noun in the genitive case (Santos et al. 2006: 921).

Carcinonemertes divae Santos, Norenburg and Bueno, 2006 (Santos et al. 2006: 917). Holotype: MZUSP 001.

Carcinonemertes sebastianensis Santos, Norenburg and Bueno, 2006 (Santos et al. 2006: 922). Holotype: MZUSP 005.

Correanemertes gordoni Gibson, 2002 (Gibson 2002: 42). Holotype: NZOI H-720.

Correanemertes polyophthalma Gibson and Sundberg, 2001 (Gibson and Sundberg 2001: 1266). Holotype: MTQ G20024.

Crybelonemertes arenicola Sundberg and Gibson, 1995 (Sundberg and Gibson 1995: 131). Holotype: WAM 23-95.

Note: Specific epithet originally spelled in the masculine gender, as "arenicolus".

Cyanonemertes elegans Iwata, 2007 (Iwata 2007: 199). Holotype: USNM sine numero.

Diopsonemertes acanthocephala Kajihara, Gibson and Mawatari, 2001 (Kajihara 
et al. 2001: 188). Holotype: ZIHU 1290.

Eonemertes xiamenensis Sun, Dong and Chen, 1998 (Sun et al. 1998: 18). Holotype: OUCQ DH22B.

Frontonemertes serpentina Iwata, 2006 (Iwata 2006: 875). Holotype: USNM 1072177.

Furugelmina heteromusculosa Chernyshev, 1998 (Chernyshev 1998a: 402). Holotype: ZMFEU no. 9/N-95.

Geonemertes philippinensis Gibson and Moore, 1998 (Gibson and Moore 1998: 164). Holotype: MHNG 977/675.

Gurjanovella murmanica Uschakov, 1926. Lectotype: ZIRAS no. 161.

Note: Originally described as a subspecies of Gurjanovella littoralis Uschakov, 1926 by Uschakov (1926: 61); Uschakov (1928: 413) also treated it as a variety, but under Article 45.6.4 of the Code (ICZN 1999) this is also deemed a subspecies; Chernyshev (1998b: 10) subsequently redescribed it as a distinct species, designating the lectotype from among Uschakov's (1926) original material.

Heilogonemertes cooki Gibson, 2002 (Gibson 2002: 68). Holotype: NZOI H-721.

Limnemertes poyangensis Gibson and Wang, 2002 (Gibson and Wang 2002: 186). Holotype: IHBCAS JX 1998015a001-101.

Malacobdella arrokeana Ivanov, Bigatti, Penchaszadeh and Norenburg, 2002 (Ivanov et al. 2002: 360). Holotype: MACN no. 34952.

Minutanemertes schifkoi Senz, 1996 (Senz 1996c: 46). Holotype: NHMW-EV 3338.

Nemertellina yamaokai Kajihara, Gibson and Mawatari, 2000 (Kajihara et al. 2000: 266). Holotype: ZIHU 1260.

Nemertopsis bullocki Coe, 1940. Lectotype: SBMNH 144754.

Note: Originally described as a variety of Nemertopsis gracilis Coe, 1940 by Coe (1940: 284), and thus deemed a subspecies under Article 45.6.4 of the Code (ICZN 1999); Hochberg and Lunianski (1998: 298) designated the lectotype from Coe's (1940) original collection; Sun and Dong (1998: 272) redescribed the taxon based on Chinese material, elevating it to the species rank.

Nemertopsis mitellicola Kajihara, 2007 (Kajihara 2007b: 51). Holotype: ZIHU 3204.

Nipponnemertes fernaldi Iwata, 2001 (Iwata 2001: 833). Holotype: USNM 1000131.

Nipponnemertes sanguinea Riser, 1998 (Riser 1998b: 288). Holotype: MNZTPT ZW1456.

Noteonemertes novaezealandiae Gibson, 2002 (Gibson 2002: 48). Holotype: NZOI $\mathrm{H}-791$.

Ototyphlonemertes ani Chernyshev, 2007 (Chernyshev 2007: 232). Holotype: MMBI 16202.

Ototyphlonemertes correae Envall, 1996 (Envall 1996: 254). Holotype: GNHM 199419.266 .

Ototyphlonemertes dolichobasis Kajihara, 2007 (Kajihara 2007c: 58). Holotype: ZIHU 3200.

Ototyphlonemertes nikolaii Chernyshev, 1998 (Chernyshev 1998c: 268). Holotype: ZMFEU 9-15048N-92.

Ototyphlonemertes valentinae Chernyshev, 2003 (Chernyshev 2003b: 868). Holotype: MMBI no. IX N-156.

Ovicides julieae Shields, 2001 (Shields 2001: 305). Holotype: QM G218108.

Pantinonemertes fujianensis Sun, 2001 (Sun 2001: 200). Holotype: OUCQ DH07.

Paranemertes sinensis Sun, 1995 (Sun 1995b: 163). Holotype: OUCQ DH108. 
Parischyronemertes mathesonensis Gibson, 2002 (Gibson 2002: 54). Holotype: NZOI H-792.

Poseidonemertes buergeri Senz, 2001 (Senz 2001a: 53). Holotype: NHMW-EV 4254 (UA 03).

Poseidonemertes giardi Senz, 2001 (Senz 2001a: 59). Holotype: NHMW-EV 4232 (ZA 15).

Poseidonemertes maslakovae Chernyshev, 2002 (Chernyshev 2002a: 909). Holotype: ZMFEU no. IX-18164.

Potamostoma shizunaiense Kajihara, Gibson and Mawatari, 2003 (Kajihara et al. 2003: 493). Holotype: ZIHU 2037.

Prosorhochmus chafarinensis Frutos, Montalvo and Junoy, 1998 (Frutos et al. 1998: 294). Holotype: MNCN 5.01/1.

Prostoma communopore Senz, 1996 (Senz 1996d: 24). Holotype: NHMW-EV 3255.

Prostoma macradenum Sun and Yin, 1995. Holotype: OUCQ DS001.

Note: Originally described as a subspecies, Prostoma eilhardi macradenum, by Sun and Yin (1995: 135); Chernyshev et al. (1998: 61) elevated it to the species rank.

Prostoma ohmiense Chernyshev, Timoshkin and Kawakatsu, 1998 (Chernyshev et al. 1998: 53). Holotype: Possibly LBM 1340000037 (see Appendix).

Pseudotetrastemma qingdaoense Sun, 1993 (Sun 1993: 1037). Holotype: OUCQ 910402I.

Note: Omitted in Gibson's (1995) checklist; specific epithet originally spelled in the masculine/feminine gender, as "qingdaoensis".

Quoyianemertes girardi Senz, 2001 (Senz 2001a: 70). Holotype: NHMW-EV 4281 (ZA 03).

Sanjuannemertes willowsi Iwata, 2006 (Iwata 2006: 905). Holotype: USNM 1072181.

Satellitenemertes satellitensis Iwata, 2006 (Iwata 2006: 888). Holotype: USNM 1072179.

Tetraneuronemertes lovgreni Sundberg, Gibson and Strand, 2007 (Sundberg et al. 2007: 2293-2298). Holotype: GNHM Nemertea 82.

Tetrastemma appendiculatum Chernyshev, 1998 (Chernyshev 1998d: 997). Holotype: ZMFEU no. 9/N-99.

Tetrastemma kangauzi Chernyshev, 2003 (Chernyshev 2003c: 19). Holotype: ZMFEU no. IX-20234.

Tetrastemma montagui Senz, 2001 (Senz 2001a: 52). Holotype: NHMW-EV 4221 (UA 06).

Tetrastemma oerstedi Senz, 2001 (Senz 2001a: 48). Holotype: NHMW-EV 4222 (ZA 03).

Tetrastemma olgarum Chernyshev, 1998 (Chernyshev 1998d: 999). Holotype: ZMFEU no. 9/N-96.

Tetrastemma pimaculatum Chernyshev, 1998 (Chernyshev 1998d: 1001). Holotype: ZMFEU no. 9/N-98.

Tetrastemma pseudocoronatum Chernyshev, 1998 (Chernyshev 1998d: 1000). Holotype: ZMFEU no. 9/N-97.

Tetrastemma tristibrunum Sundberg and Gibson, 1995 (Sundberg and Gibson 1995: 136). Holotype: WAM 25-95.

Note: Specific epithet originally spelled in the feminine gender, as "tristibruna". 
Thallassionemertes leucocephala Gibson and Sundberg, 2001 (Gibson and Sundberg 2001: 1262). Holotype: MTQ G20023.

Thermanemertes valens Rogers, Gibson and Tunnicliffe, 1996 (Rogers et al. 1996: 1583). Holotype: USNM 170038.

Typhloerstedia anadonae Chernyshev, 1999. Holotype: Unspecified; location of type lot unknown.

Note: Chernyshev (1999a: 946) regarded Oerstedia vittata Hubrecht, 1879 sensu Anadon and Bitar (1992) as different from Oerstedia vittata Hubrecht, 1879 s. str. and included it in a new genus.

Verrillianemertes rathkei Senz, 2001 (Senz 2001a: 62). Holotype: NHMW-EV 4267 (ZA 11).

Verrillianemertes schultzei Senz, 2001 (Senz 2001a: 65). Holotype: NHMW-EV 4263 (UA 08).

Vulcanonemertes rangitotoensis Gibson and Strand, 2002 (Gibson and Strand 2002: 3). Holotype: MNZTPT 1511.

Zygonemertes jamsteci Kajihara, 2002 (Kajihara 2002: 131). Holotype: ZIHU 1928.

Zygonemertes shintai Kajihara, 2002 (Kajihara 2002: 122). Holotype: ZIHU 1926.

Zygonemertes wadjemupensis Gibson, 1999 (Gibson 1999: 366). Holotype: WAM 2097.

Taxonomic changes of nemertean genera made after 1995

PALAEONEMERTEA

Cephalotrichella Wijnhoff, 1913: synonymized with Cephalothrix Örsted, 1843 by Sundberg et al. (2003: 292).

Procephalothrix Wijnhoff, 1913: synonymized with Cephalothrix Örsted, 1843 by Sundberg et al. (2003: 292).

PILIDIOPHORA

Coeia Takakura, 1922: synonymized with Hubrechtella Bergendal, 1902 by Kajihara (2006: 27); formerly regarded as belonging to the Palaeonemertea, here transferred to the Pilidiophora.

Hubrechtella Bergendal, 1902: formerly regarded as belonging to the Palaeonemertea, but transferred to the Pilidiophora by Thollesson and Norenburg (2003).

Myoisophagos Riser, 1994: listed as valid in Gibson (1995: 422); a junior synonym of Ramphogordius Rathke, 1843 (Riser 1998a: 154).

Nemertoscolex Greeff, 1879: omitted from Gibson's (1995) checklist; a diagnosis was given by Berg and Gibson (1996: 164).

Polydendrorhynchus Yin and Zeng, 1986: synonymized with Dendrorhynchus Yin and Zeng, 1985 by Sun (2006: 962). The latter, however, was preoccupied by Dendrorhynchus Keilin, 1920 (q.v.) (Protozoa: Apicomplexa: Gregarinea). Here, Polydendrorhynchus is recognized as the substitute name for Dendrorhynchus Yin and Zeng, 1985, according to Article 60.2 of the Code (ICZN 1999).

Poseidon Girard, 1852: listed as a junior synonym of Lineus Sowerby, 1806 (type species: Ascaris longissima Gunnerus, 1770) by Verrill (1892: 417); the type species, Poseidon colei Girard, 1852, was synonymized with Lineus ruber (Müller, 1774) by Bürger (1904: 101); listed as an invalid name by Gibson (1995: 487); Chernyshev (2004b) regarded Lineus ruber (Müller, 1774) and Lineus 
viridis (Müller, 1774) as not belonging to Lineus, and resurrected the generic name to accommodate Poseidon ruber (Müller, 1774) and Poseidon viridis (Müller, 1774).

Ramphogordius Rathke, 1843: mistakenly listed as an invalid name by Gibson (1995: 503); a senior synonym of Myoisophagos Riser, 1994 (Riser 1998a: 154).

Riserius Norenburg, 1993: listed as a genus of uncertain affiliation to higher taxon by Gibson (1995: 504). Thollesson and Norenburg's (2003) molecular phylogenetic analysis indicated that it belongs to the Pilidiophora.

Tetramys Iwata, 1957: formerly regarded as belonging to the Palaeonemertea, but here tentatively treated it as the member of the Pilidiophora, based on its similarity to Hubrechtella.

MONOSTILIFERA

Akrostomum Grube, 1840: listed as an invalid name by Gibson (1995: 275). The ICZN (2003: 59) ruled that the name is valid and placed it on the Official List of Generic Names in Zoology (ICZN 2007); see also Valdivianemertes Stiasny-Wijnhoff, 1923.

Malacobdella Blainville, 1827: formerly regarded as comprising a distinct higher taxon, the Bdellonemertea. Thollesson and Norenburg's (2003) molecular phylogenetic study indicated that this genus should be treated as a member of the Monostilifera.

Psammamphiporus Gibson, 1989: synonymized with Amphiporus Ehrenberg, 1831 by Chernyshev (1998a: 397-398).

Tagonemertes Corrêa, 1957: synonymized with Amphiporus Ehrenberg, 1831 by Chernyshev (1998a: 397-398).

Valdivianemertes Stiasny-Wijnhoff, 1923: the validity of the name was discussed by Chernyshev (1992) and Crandall (1993); listed as a valid name by Gibson (1995: 532). Crandall (1994) proposed conservation of the name against its senior synonym Akrostomum, but the ICZN (2003: 59) ruled that priority should be maintained and placed the name Valdivianemertes on the Official Index of Rejected and Invalid Generic Names in Zoology (ICZN 2007).

REPTANTIA

Coella Stiasny-Wijnhoff, 1936: a monotypic genus established by Stiasny-Wijnhoff (1936: 72) with Coella tiurensis Stiasny-Wijnhoff, 1936 as the type species. Härlin (1998) referred to this species as Punnettia tiurensis based on a cladistic analysis of morphological characters by Härlin and Sundberg (1995), essentially but not explicitly synonymizing Coella with Punnettia Stiasny-Wijnhoff, 1926.

Curranemertes Kirsteuer, 1973: a monotypic genus established by Kirsteuer (1973: 138) with Curranemertes natans Kirsteuer, 1973 as the type species. Härlin (1998) referred to this species as Punnettia natans based on a cladistic analysis of morphological characters by Härlin and Sundberg (1995), essentially but not explicitly synonymizing Curranemertes with Punnettia.

Drepanophoria Stiasny-Wijnhoff, 1936: a monotypic genus established by StiasnyWijnhoff (1936: 32) with Drepanophoria pajungae Stiasny-Wijnhoff, 1936 as the type species. Härlin (1998) referred to this species as Drepanophorella pajungae based on a cladistic analysis of morphological characters by Härlin and Sundberg (1995), essentially but not explicitly synonymizing Drepanophoria with Drepanophorella Stiasny-Wijnhoff, 1936. 
Drepanophoresta Gibson, 1995: first proposed by Stiasny-Wijnhoff (1936: 23) to contain Drepanophorus lifuensis Punnett, 1900 and Drepanophorus roseus Punnett, 1903, without type fixation. The generic name was thus unavailable under Article 13.3 of the Code (ICZN 1999) until Gibson (1995: 357) subsequently designated Drepanophorus roseus as the type species. Härlin (1998) referred to the two species as Drepanophorella lifuensis and Drepanophorella rosea based on a cladistic analysis of morphological characters by Härlin and Sundberg (1995), essentially but not explicitly synonymizing Drepanophoresta with Drepanophorella.

Drepanophoringia Stiasny-Wijnhoff, 1936: a monotypic genus established by Stiasny-Wijnhoff (1936: 37) with Drepanophoringia waingapuensis Stiasny-Wijnhoff, 1936 as the type species. Härlin (1998) referred to this species as Drepanophorella waingapuensis based on a cladistic analysis of morphological characters by Härlin and Sundberg (1995), essentially but not explicitly synonymizing Drepanophoringia with Drepanophorella.

Hubrechtonemertes Stiasny-Wijnhoff, 1934: a monotypic genus established by Stiasny-Wijnhoff (1934: 168) with Drepanophorus lankesteri Hubrecht, 1887 as the type species. Härlin (1998) referred to this species as Punnettia lankesteri based on a cladistic analysis of morphological characters by Härlin and Sundberg (1995), essentially but not explicitly synonymizing Hubrechtonemertes with Punnettia Stiasny-Wijnhoff, 1926.

Urichonemertes Gibson, 1983: a monotypic genus established by Gibson (1983: 75) with Urichonemertes pilorhynchus Gibson, 1983 as the type species. Härlin (1998) referred to this species as Punnettia pilorhynchus based on a cladistic analysis of morphological characters by Härlin and Sundberg (1995), essentially but not explicitly synonymizing Urichonemertes with Punnettia.

Xenonemertes Gibson, 1983: a monotypic genus established by Gibson (1983: 91) with Xenonemertes rhamphocephalus Gibson, 1983 as the type species. Härlin (1998) referred to this species as Punnettia rhamphocephalus based on a cladistic analysis of morphological characters by Härlin and Sundberg (1995), essentially but not explicitly synonymizing Xenonemertes with Punnettia.

PELAGICA

Bathynemertes Laidlaw, 1906: listed by Gibson (1995: 305) as a genus of uncertain affiliation to higher taxon; Maslakova and Norenburg (2001) regarded it as belonging to the Pelagica.

Nemertobus Chernyshev, 1992: synonymized with Obnemertes Prudhoe, 1963 by Chernyshev and Chaban (2005: 154).

Changes in validity of species names and alterations of generic affiliation made after 1995

PALAEONEMERTEA

Cephalotrichella alba Gibson and Sundberg, 1992: now Cephalothrix alba (Gibson and Sundberg, 1992) as the result of Sundberg et al.'s (2003: 292) synonymization of Cephalotrichella Wijnhoff, 1913 with Cephalothrix Örsted, 1843.

Cephalotrichella signata (Hubrecht, 1879): originally placed in the genus Cephalothrix, later transferred to the genus Cephalotrichella by Wijnhoff (1913), which was regarded as a junior synonym of the former by Sundberg et al. (2003: 292); now again Cephalothrix signata Hubrecht, 1879. 
Procephalothrix adriatica Senz, 1993: now Cephalothrix adriatica (Senz, 1993) as the result of Sundberg et al.'s (2003: 292) synonymization of Procephalothrix Wijnhoff, 1913 with Cephalothrix.

Procephalothrix aliena (Punnett, 1903): originally placed in the genus Cephalothrix, later transferred by Wijnhoff (1913) to the genus Procephalothrix, which Sundberg et al. (2003: 292) regarded as a junior synonym of Cephalothix; now again Cephalothrix aliena Punnett, 1903.

Procephalothrix arenaria Gibson, 1990: the specific epithet was originally spelled in the masculine gender as "arenarius"; now Cephalothrix hongkongiensis Sundberg, Gibson and Olsson, 2003, a replacement name proposed to avoid secondary homonymy with Cephalothrix arenaria Hylbom, 1957 when Procephalothrix was synonymized with Cephalothrix by Sundberg et al. (2003: 292).

Procephalothrix fasciculus Iwata, 1952: now Cephalothrix fasciculus (Iwata, 1952) as the result of Sundberg et al.'s (2003: 292) synonymization of Procephalothrix with Cephalothrix. The specific epithet is a Latin diminutive noun of the masculine gender, and thus should not be spelled as "fascicula" (Kajihara 2007d: 294).

Procephalothrix filiformis (Johnston, 1828): originally described as Planaria filiformis Johnston, 1828, transferred to Cephalothrix by McIntosh (1867: 92), then to Procephalothrix by Wijnhoff (1913: 295); now Cephalothrix filiformis (Johnston, 1828) as the result of Sundberg et al.'s (2003: 292) synonymization of Procephalothrix with Cephalothrix.

Procephalothrix hermaphroditica Gibson, Sánchez and Méndez, 1990: the specific epithet was originally spelled in the masculine gender as "hermaphroditicus"; now Cephalothrix hermaphroditica (Gibson, Sánchez and Méndez, 1990) as the result of Sundberg et al.'s (2003: 292) synonymization of Procephalothrix with Cephalothrix 1843.

Procephalothrix kiliensis Friedrich, 1935: now Cephalothrix kiliensis (Friedrich, 1935) as the result of Sundberg et al.'s (2003: 292) synonymization of Procephalothrix with Cephalothrix.

Procephalothrix major (Coe, 1930): originally described in the genus Cephalothrix, later transferred to Procephalothrix by Coe (1940: 257); now again Cephalothrix major Coe, 1930 as the result of Sundberg et al.'s (2003: 292) synonymization of Procephalothrix with Cephalothrix.

Procephalothrix mokievskii Korotkevich, 1982: now Cephalothrix mokievskii (Korotkevich, 1982) as the result of Sundberg et al.'s (2003: 292) synonymization of Procephalothrix with Cephalothrix.

Procephalothrix oestrymnica Junoy and Gibson, 1991: the specific epithet was originally spelled in the masculine gender as "oestrymnicus"; now Cephalothrix oestrymnica (Junoy and Gibson, 1991) as the result of Sundberg et al.'s (2003: 292) synonymization of Procephalothrix with Cephalothrix.

Procephalothrix orientalis Gibson, 1990: now Cephalothrix orientalis (Gibson, 1990) as the result of Sundberg et al.'s (2003: 292) synonymization of Procephalothrix with Cephalothrix.

Procephalothrix quequenensis Moretto, 1974: now Cephalothrix quequenensis (Moretto, 1974) as the result of Sundberg et al.'s (2003: 292) synonymization of Procephalothrix with Cephalothrix. 
Procephalothrix simula Iwata, 1952: the specific epithet was originally spelled in the masculine gender as "simulus"; now Cephalothrix simula (Iwata, 1952) as the result of Sundberg et al.'s (2003: 292) synonymization of Procephalothrix with Cephalothrix.

Procephalothrix spiralis (Coe, 1930): originally placed in the genus Cephalothrix, transferred to Procephalothrix by Coe (1940: 258); now again Cephalothrix spiralis Coe, 1930 as the result of Sundberg et al.'s (2003: 292) synonymization of Procephalothrix with Cephalothrix.

Tubulanus theeli (Bergendal, 1902): designated as the type species of Protubulanus Chernyshev, 1995 (Chernyshev 1995: 11), so now Protubulanus theeli (Bergendal, 1902).

PILIDIOPHORA

Baseodiscus curtus (Hubrecht, 1879): synonymized with Baseodiscus delineatus (Delle Chiaje, 1825) by Gibson (1979), but Crandall et al. (2002) noted these two forms should be retained as separate species. Hubrecht (1879: 209) mentioned that the two species can be distinguished by the presence and absence, respectively, of longitudinal stripes on the ventral surface of the body.

Baseodiscus takakurai Gibson, 1995: Takakura (1898) recorded Eupolia sp., commenting that it resembled Eupolia antillensis Bürger, 1895. Gibson (1995: 305) misinterpreted this as Takakura's (1898) having established a new taxon with the specific epithet antillensis, and superfluously proposed the new replacement name Baseodiscus takakurai Gibson, 1995 (Kajihara 2007d: 303).

Borlasia bilineata Schmarda, 1859: uncertainly synonymized with Lineus bilineatus (Renier, 1804) by Bürger (1904: 94); Gibson (1995: 306) doubted the conspecificity of these species, but regarded Borlasia bilineata as invalid. Later, Senz (1997a: 430) redescribed Schmarda's (1859) type material (syntypes: NHMW-EV $52000 / 3581$ and NHMW-EV 3582) and transferred the species to the genus Baseodiscus Diesing, 1850; now Baseodiscus bilineatus (Schmarda, 1859).

Borlasia trilineata Schmarda, 1859: listed by Bürger (1904: 126) as a dubious species, regarded as an invalid name by Gibson (1995: 312), but Senz (1996e: 32) redescribed the taxon using Schmarda's (1859) type material (holotype: NHMW-EV 5215/3337) and transferred it to the genus Lineopsella Friedrich, 1970; now Lineopsella trilineata (Schmarda, 1859).

Cerebratulus knerii (Diesing, 1850): originally described as Meckelia knerii, later transferred to Cerebratulus by Brüger (1904: 123); although listed as a valid name by Gibson (1995: 336), it had been synonymized by Senz (1994: 242) with Notospermus geniculatus based upon examination of specimens including a topotype of $C$. knerii identified by Diesing (NHMW EV 3321); now Notospermus geniculatus (Delle Chiaje, 1828).

Cerebratulus kowalewskii Timofeev, 1913: herein regarded as available and valid, although listed as an unavailable name by Gibson (1995: 336). Gibson (1995) was evidently unaware of Timofeev's (1913: 214) description and thus erroneously attributed the authorship to Antipa (1941) while declaring it a nomen nudum therein. The type material is deposited in ZIRAS (AVC, pers. obs.).

Coeia ijimai Takakura, 1922: redescribed as Hubrechtella ijimai (Takakura, 1922) by Kajihara (2006: 28).

Dendrorhynchus sinensis Yin and Zeng, 1985: synonymized with Dendrorhynchus 
zhanjiangensis Yin and Zeng, 1984 along with Polydendrorhynchus papillaris Yin and Zeng, 1986 by Sun (2006: 944) based on comparison of the holotypes (OUCQ Zhanjiang-8304 for D. sinensis, OUCQ Zhanjiang-8403 for D. zhanjiangensis, and OUCQ Zhanjiang-8409 for P. papillaris). However, because Dendrorhynchus Yin and Zeng, 1985 is preoccupied by Dendrorhynchus Keilin, 1920 (q.v.) (Protozoa: Apicomplexa: Gregarinea), these species should now be referred to as Polydendrorhynchus zhanjiangensis (Yin and Zeng, 1984) comb. nov. according to Article 60.2 of the Code (ICZN 1999). See also Polydendrorhynchus.

Lineus albovittatus (Stimpson, 1855): listed as an invalid name by Gibson (1995: 391); originally described from Okinawa, Japan, as Meckelia albovittata, later synonymized with Lineus tricuspidatus (Quoy and Gaimard, 1833) by Gibson (1981: 206), who was, however, quite aware that the color pattern of the Japanese form is different from the records of other authors and "appears to be of a different species" (Gibson, 1981: 207). Kajihara (2007d: 299) regarded the species as valid.

Lineus arenicolus Senz, 1993: listed as an invalid name by Gibson (1995: 392) for the reason of homonymy with Lineus arenicolus (Verrill, 1873). Senz (1995: 55) replaced the name with Lineus rovinjensis Senz, 1995.

Lineus gurjanovae Korotkevich, 1977: listed as a valid species in Gibson (1995: 397), but synonymized with Poseidon viridis (Müller, 1774) by Chernyshev (2004b: 790).

Lineus longifissus (Hubrecht, 1887): listed as a valid species in Gibson (1995: 399). It was originally described as Cerebratulus longifissus, which was later designated as the type species of the genus Heteronemertes Chernyshev, 1995 (Chernyshev 1995: 15); now Heteronemertes longifissa (Hubrecht, 1887).

Lineus ruber (Müller, 1774): listed as a valid name by Gibson (1995: 401); it is controversial whether its original name was Ascaris rubra Müller, 1774 or Fasciola rubra Müller, 1774 (Gibson 1995: 374); transferred to Poseidon Girard, 1852 by Chernyshev (2004b); now Poseidon ruber (Müller, 1774).

Lineus schmardai Bürger, 1904: listed as a valid name by Gibson (1995: 402), now Myorhynchonemertes striata (Schmarda, 1859); see Meckelia striata Schmarda, 1859.

Lineus uschakovi Korotkevich, 1977: listed as a valid species by Gibson (1995: 403), but synonymized with Poseidon viridis (Müller, 1774) by Chernyshev (2004b: 790).

Lineus viridis (Müller, 1774): originally described as Fasciola viridis Müller, 1774; transferred to Lineus Sowerby, 1806 (type species: Ascaris longissima Gunnerus, 1770) by Verrill (1879: 185); listed as a valid name by Gibson (1995: 404); transferred to Poseidon Girard, 1852 by Chernyshev (2004b); now Poseidon viridis (Müller, 1774).

Meckelia striata Schmarda, 1859: listed as an invalid name by Gibson (1995: 412), having previously, on uncler grounds (possibly to avoid secondary homonymy with Lineus striatus Griffin, 1898), been renamed as Lineus schmardai Bürger, 1904 (Bürger 1904: 93). Senz (1997a: 483) redescribed Schmarda's (1859) type material (syntypes: NHMW-EV 5212/3574, 3575, and 5211/3588) and transferred this species to a newly established genus as Myorhynchonemertes striata (Schmarda, 1859). 
Micrura aurantiaca (Grube, 1855): originally described as Meckelia aurantiaca from Villefranche-sur-Mer, France, by Grube (1855: 148), later transferred to Micrura by McIntosh (1873-1874: 201), and listed by Gibson (1995: 415) as a valid name. Later, Cantell (1996: 116) redescribed the species based on material collected from Banyuls-sur-Mer, France, and transferred it to Leucocephalonemertes Cantel, 1996; now Leucocephalonemertes aurantiaca (Grube, 1855).

Micrura leidyi (Verrill, 1892): listed as a valid name by Gibson (1995: 418). The species was first described by Leidy (1851: 244) as Meckelia rosea. Later Verrill (1892: 436) described Cerebratulus leidyi and regarded it as conspecific with Leidy's Meckelia rosea. Coe (1943: 250) transferred the species to the genus $\mathbf{M i}$ crura but erroneously used the specific epithet as leidyi. The species is now classified as Fragilonemertes rosea (Leidy, 1851) (Riser 1998a: 150).

Micrura uchidai Yamaoka, 1940: listed as a valid name by Gibson (1995: 420), later designated as the type species of Nipponomicrura by Chernyshev (1995: 15); now Nipponomicrura uchidai (Yamaoka, 1940).

Myoisophagos lacteus (Rathke, 1843): originally described by Rathke (1843: 238) as the sole member of the genus Ramphogordius Rathke, 1843. Riser (1994: 553) redescribed the species as Myoisophagos lacteus, establishing a superfluous genus Myoisophagos Riser, 1994. Gibson (1995: 423) listed Myoisophagos lacteus as a valid name, but Riser (1998a: 154) acknowledged that Myoisophagos is a junior synonym of Ramphogordius Rathke, 1843. Ramphogordius lacteus Rathke, 1843 is the valid name for this taxon.

Myoisophagos pseudolacteus (Gontcharoff, 1951): established by Gontcharoff (1951: 157) as Lineus pseudolacteus; redescribed by Riser (1994: 552) as Myoisophagos pseudolacteus. Gibson (1995: 423) listed Myoisophagos pseudolacteus as a valid name, but Riser (1998a: 154) acknowledged that Myoisophagos is a junior synonym of Ramphogordius. Ramphogordius pseudolacteus (Gontcharoff, $1951)$ is the valid name for this taxon.

Myoisophagos sanguineus (Rathke, 1799): established by Rathke (1799: 83) as Planaria sanguinea; redescribed by Riser (1994: 549) as Myoisophagos sanguineus. Gibson (1995: 423) listed Myoisophagos sanguineus as a valid name, but Riser (1998a: 154) acknowledged that Myoisophagos is a junior synonym of Ramphogordius. Ramphogordius sanguineus (Rathke, 1799) is the valid name for this taxon.

Nemertoscolex parasiticus Greeff, 1879: originally reported as an endoparasite of the echiuran Echiurus pallasii (now Echiurus echiurus Pallas, 1766) by Greef (1879: 130); omitted from Gibson's (1995) checklist; redescribed by Berg and Gibson (1996: 164) based on newly obtained material from Sweden in 1964, one of these specimens being designated as the neotype, SMNH 4648.

Polydendrorhynchus papillaris Yin and Zeng, 1986: synonymized with Dendrorhynchus zhanjiangensis Yin and Zeng, 1984 along with Dendrorhynchus sinensis Yin and Zeng, 1985 by Sun (2006: 944) based on comparison of the holotypes (OUCQ Zhanjiang-8304 for D. sinensis, OUCQ Zhanjiang-8403 for D. zhanjiangensis, and OUCQ Zhanjiang-8409 for P. papillaris). However, because Dendrorhynchus Yin and Zeng, 1985 is preoccupied by Dendrorhynchus Keilin, 1920 (q.v.) (Protozoa: Apicomplexa: Gregarinea), the species should now be referred to as Polydendrorhynchus zhanjiangensis (Yin and Zeng, 1984) comb. nov., 
according to Article 60.2 of the Code (ICZN 1999). See also Polydendrorhynchus. MONOSTILIFERA

Amphiporus heterophthalmus (Schmarda, 1859): listed as a valid name by Gibson (1995: 285). Later Senz (1997b: 193) redescribed Schmarda's (1859) type material (syntypes: NHMW-EV 2562, 5179/3559, 3560, 3561, and 16710) and transferred this species to the genus Ischyronemertes Gibson, 1990; now Ischyronemertes heterophthalma (Schmarda, 1859).

Amphiporus nelsoni Sánchez, 1973: listed as a valid name by Gibson (1995: 290), redescribed by Maslakova et al. (2005: 484) and transferred to Prosorhochmus Keferstein, 1862; now Prosorhochmus nelsoni (Sánchez, 1973).

Amphiporus rubellus Coe, 1905: listed as a valid name by Gibson (1995: 293). Gibson and Crandall (1989: 467) mentioned the taxon as a probable cratenemeritid. Crandall and Norenburg (1999) listed the species as a member of the genus Nipponnemertes based on observation of Coe's (1905) type material in the Peabody Museum of Natural History at Yale University (FBC, pers. obs.); now Nipponnemertes rubella (Coe, 1905).

Antarctonemertes quasioculata (Korotkevich, 1977): listed as a valid name by Gibson (1995: 297), later synonymized with Antarctonemertes papilliformis (Korotkevich, 1977) by Chernyshev (1999a: 940).

Nipponnemertes scoresbyi (Wheeler, 1934): originally described as Amphiporus scoresbyi, transferred to Nipponnemertes by Berg (1985: 244), listed as a valid name by Gibson (1995: 442), later redescribed by Crandall and Gibson (1998: 174) based upon Wheeler's (1934) type material as Achoronemertes scoresbyi (Wheeler, 1934).

Oerstedia nigrimaculata (Gibson, 1988): originally described as Paroerstedia nigrimaculata by Gibson (1988: 734); listed as a valid species in Gibson (1995: 445) according to Envall and Sundberg's (1993) synonymization of the genus Paroerstedia Friedrich, 1955 with Oerstedia Quatrefages, 1846. Later, however, Sundberg and Andersson (1995: 489) concluded that Oerstedia nigrimaculata (Gibson, 1988) is a junior synonym of Oerstedia dorsalis (Abildgaard, 1806) based on a random amplified polymorphic DNA analysis.

Paranemertes biocellata Coe, 1944: the specific epithet was originally spelled in the masculine gender as "biocellatus"; designated as the type species of Kirsteueriella by Chernyshev (2002a: 915); now Kirsteueriella biocellata (Coe, 1944).

Psammamphiporus elongatus (Stephenson, 1911): now Amphiporus elongatus Stephenson, 1911, as a result of Chernyshev's (1998a: 397-398) synonymization of Psammamphiporus Gibson, 1989 with Amphiporus Ehrenberg, 1831.

Psammamphiporus microocelli Sun, 1995: now Amphiporus microocelli (Sun, 1995), as a result of Chernyshev's (1998a: 397-398) synonymization of Psammamphiporus with Amphiporus.

Tagonemertes tuba Corrêa, 1957: now Amphiporus tuba (Corrêa, 1957), as a result of Chernyshev's (1998a: 397-398) synonymization of Tagonemertes Corrêa, 1957 with Amphiporus.

Tetrastemma bicolor Coe, 1901: transferred to Quasitetrastemma by Chernyshev (2004a: 154); now Quasitetrastemma bicolor (Coe, 1901).

Tetrastemma commensalis (Kyao, 1954): the original description of the species contained two different spellings, "commensalus" (Kyao 1954: 135, 138) and "com- 
mensalis" (Kyao 1954: 139), in combination with the generic name Amphiporus. The species was transferred from Amphiporus to Tetrastemma by Chernyshev (1991: 34), then further to Asteronemertes by Chernyshev (1998d: 995). The species name has been cited variously as "Tetrastemma (=Amphiporus) commensalus" and "Tetrastemma commensalis" (Chernyshev 1991; the two spellings appearing once and several times, respectively), "Tetrastemma commensalis (Kayo [sic], 1954)" (Senz 1997c), "T. commensalis" and "Amphiporus commensalis" (Chernyshev 1998d), "Asteronemertes commensalis (Kyao, 1954)" (Crandall et al. 2002), and "A. [=Asteronemertes] commensalus" (Jensen and Sadeghian 2005). Gibson (1995) was clearly aware that the specific epithet was spelled in two different ways in Kyao's original article (Gibson 1995: 281) and listed Amphiporus commensalus Kyao, 1954 as having precedence (Gibson 1995: 280). Taken alone, this nomenclatural act could evidently be regarded as the selection of the correct original spelling by the First Reviser, as stipulated in Article 24.2.3 of the Code (ICZN 1999); confusingly, however, on other pages in the same paper Gibson (1995: 281, 513) used Tetrastemma commensalis as the valid name. Consequently, Gibson's (1995) action as a whole appears rather indecisive. Amphiporus commensalis Kyao, 1954 is here selected as the correct original spelling. The specific epithet is an adjective. Thus the valid name for this taxon is Asteronemertes commensalis (Kyao, 1954).

Tetrastemma dilutebasisae Kulikova, 1987: transferred to Antarctonemertes Friedrich, 1955 by Chernyshev (1999a: 941); now Antarctonemertes dilutebasisae (Kulikova, 1987).

Tetrastemma kirsteueri Senz, 1995: Senz (1995: 55) replaced the name Tetrastemma cruciatus Senz, 1993 to avoid homonymy with Tetrastemma cruciatum Bürger, 1895.

Tetrastemma nigrifrons Coe, 1904: designated as the type species of Quasitetrastemma Chernyshev, 2004 by Chernyshev (2004a: 154); now Quasitetrastemma nigrifrons (Coe, 1904).

Tetrastemma phyllospadicola Stricker, 1985: transferred to Antarctonemertes Friedrich, 1955 by Chernyshev (1999a: 940); now Antarctonemertes phyllospadicola (Stricker, 1985).

Tetrastemma kulikovae Gibson, 1995: Gibson (1995: 527) regarded Tetrastemma viridis Kulikova, 1989 as secondarily homonymous with Örsted's (1844) usage of Tetrastemma viridis (=Planaria viridis Müller, 1774) and proposed the new replacement name Tetrastemma kulikovae Gibson, 1995. Chernyshev (1998d) argued that Tetrastemma viridis sensu Örsted (1844) had long since been transferred to the genus Lineus, and that there was no homonymy in 1995; under Article 59.4 of the Code (ICZN 1999), the specific name viridis Kulikova was thus reinstated. Later, Chernyshev (2004a) redescribed Tetrastemma viridis Kulikova, 1989 and transferred it to the genus Protetrastemma Chernyshev, 2004; its current valid name is Protetrastemma viride (Kulikova, 1989).

Tetrastemma stimpsoni Chernyshev, 1992: Yamaoka (1940: 251) reported a taxon under the name "Prostoma stigmatum (Stimpson, 1857)"; Chernyshev (1992: 135) regarded Yamaoka's (1940) taxon as different from Tetrastemma stigmatum Stimpson, 1857, and established a new name Tetrastemma stimpsoni for the former; later, Chernyshev (2004a: 154) erected a new genus Quasite- 
trastemma and transferred Tetrastemma stimpsoni to it, erroneously under the name "Quasitetrastemma stigmatum (Yamaoka, 1940)"; Kajihara (2007d: 312) argued that the species should correctly be referred to as Quasitetrastemma stimpsoni (Chernyshev, 1992).

Tetrastemma tridentatum Korotkevich, 1977: the specific epithet was originally spelled in the feminine gender, as "tridentata". It was listed as a valid name by Gibson (1995: 525), but Chernyshev (1998d) regarded it as a nomen dubium.

Valdivianemertes stannii (Grube, 1840): now Akrostomum stannii Grube, 1840 as the result of ICZN's (2003: 59) ruling on the priority of Akrostomum Grube, 1840 over its junior synonym Valdivianemertes Stiasny-Wijnhoff, 1923. See also Akrostomum.

Valdivianemertes valdiviae (Bürger, 1909): listed as a valid name in Gibson (1995); now Akrostomum valdiviae (Bürger, 1909) as mentioned above.

REPTANTIA

Amphiporus parmiornatus Iwata, 1957: Iwata (1998: 200) redescribed the type material and transferred the species to Kameginemertes Iwata, 1998; now Kameginemertes parmiornata (Iwata, 1957).

Coella tiurensis Stiasny-Wijnhoff, 1936: Härlin (1998) referred to this species as Drepanophorella tiurensis based on a cladistic analysis of morphological characters by Härlin and Sundberg (1995); now Drepanophorella tiurensis (Stiasny-Wijnhoff, 1936).

Curranemertes natans Kirsteuer, 1973: Härlin (1998) referred to this species as Punnettia natans based on the analysis mentioned above; now Punnettia natans (Kirsteuer, 1973).

Drepanophoresta lifuensis (Punnett, 1900): originally described by Punnett (1900: 573) as Drepanophorus lifuensis, subsequently redescribed as Drepanophoresta lifuensis by Stiasny-Wijnhoff (1936: 27). Härlin (1998) referred to this species as Drepanophorella lifuensis based on the analysis mentioned above; now Drepanophorella lifuensis (Punnett, 1900).

Drepanophoresta rosea (Punnett, 1903): originally described by Punnett (1903: 112) as Drepanophorus roseus, subsequently redescribed as Drepanophoresta rosea by Stiasny-Wijnhoff (1936: 23). Härlin (1998) referred to this species as Drepanophorella rosea based on the analysis mentioned above; now Drepanophorella rosea (Punnett, 1903).

Drepanophoria pajungae Stiasny-Wijnhoff, 1936: Härlin (1998) referred to this species as Drepanophorella pajungae based on the analysis mentioned above; now Drepanophorella pajungae (Stiasny-Wijnhoff, 1936).

Drepanophoringia wangipauensis Stiasny-Wijnhoff, 1936: Härlin (1998) referred to this species as Drepanophorella wangipauensis based on the analysis mentioned above; now Drepanophorella wangipauensis (Stiasny-Wijnhoff, 1936).

Hubrechtonemertes lankesteri (Hubrecht, 1887): Härlin (1998) referred to this species as Punnettia lankesteri based on the analysis mentioned above; now Punnettia lankesteri (Hubrecht, 1887).

Urichonemertes pilorhynchus Gibson, 1983: Härlin (1998) referred to this species as Punnettia pilorhynchus based on the analysis mentioned above; now Punnettia pilorhynchus (Gibson, 1983); because Gibson (1983: 75) did not indicate whether the specific epithet is a noun or an adjective, it should be treated as a noun in apposition to the generic name, according to Article 31.2.2 of the Code 
(ICZN 1999).

Xenonemertes rhamphocephalus Gibson, 1983: Härlin (1998) referred to this species as Punnettia rhamphocephalus based on the analysis mentioned above; now Punnettia rhamphocephalus (Gibson, 1983); because Gibson (1983: 91) did not indicate whether the specific epithet is a noun or an adjective, it should be treated as a noun in apposition to the generic name, according to Article 31.2.2 of the Code (ICZN 1999).

PELAGICA

Nectonemertes compacta Korotkevich, 1964: transferred to Chuniella Brinkman, 1917 by Chernyshev and Chaban (2005: 152); now Chuniella compacta (Korotkevich, 1964).

Pelagonemertes parvula Korotkevich, 1964: transferred to Balaenanemertes Bürger, 1909 by Chernyshev and Chaban (2005: 154); now Balaenanemertes parvula (Korotkevich, 1964).

\section{Unavailable genus-group names}

The following names proposed by Härlin (1998) and each used by him as a part of a binomen, as if representing a genus name, cannot be considered generic names in terms of the Code (ICZN 1999): Bergia, Crandallia, Fumionemertes, Gerardanemertes, Gibsonnemertes, and Wijnhoffia. These were defined in terms of clade boundaries, not character-based diagnoses, so they do not meet Article 13.1.1 of the Code (ICZN 1999) and are unavailable names. In addition, Bergia is preoccupied by Bergia Duchassaing and Michelotti, 1860 (q.v.) (Cnidaria: Anthozoa). We consider, however, that the other nomenclatural acts at the genus level and the new combinations of available generic and specific names made by Härlin (1998) are valid. On the other hand, the nomenclatural acts taken by Härlin and Härlin (2001) are unavailable because their paper did not employ binominal nomenclature (Article 5.1 of the Code: ICZN 1999) and thus failed to meet the criteria of Article 11.4 of the Code (ICZN 1999).

Korotneff (1901: 309-310) reported a worm species from Olkhon Island in Lake Baikal; the worms reached $10-15 \mathrm{~mm}$ in length and were light yellow in color. They had neither cerebral organs nor eyes, but did have a mouth opening immediately behind the brain and a proboscis pore at the tip of the head. The proboscis possessed a stylet shaped like a Turkish saber, without accessory stylets or accessory stylet pouches. The worms were probably viviparous. Korotneff (1901) considered them to be nemerteans, although they probably represent some form of turbellarian (Dr Oleg Timoshkin, pers. comm.). To refer to this worm, Korotneff (1901: 310) used a name Baicalonemertes that is not listed in Gibson's (1995) checklist. We regard this name as unavailable, since it was not combined with any specific name and thus does not satisfy Article 12.2.5 of the Code (ICZN 1999). Korotneff (1901) himself appears to have had no intention of using it as a scientific name, because it is printed in roman type within double quotation marks, as opposed to italic type which he consistently used throughout the rest of the article for scientific names.

As was discussed by Chernyshev (1998a, c), the two subgeneric names Intestinonemertes and Otohelicophora proposed by Friedrich (1957) and Envall (1996), respectively, are unavailable due to the lack of type fixation in the original publication [Article 13.3 of the Code (ICZN 1999)]. To our knowledge, no subsequent designation has been made, which would have made these names available under other 
authorship.

\section{Unavailable species name}

Korotkevich (1982: 42) used a name Carinina chupensis [not listed in Gibson's (1995) checklist] for what she identified as a new species. She did not supply a description of the species, and thus this name is a nomen nudum.

\section{Acknowledgements}

We thank Dr Ray Gibson (Professor Emeritus of Liverpool John Moores University, UK) for comments on the original draft of this paper. We are also grateful to Dr Mark J. Grygier (Lake Biwa Museum, Japan) for a number of extremely valuable suggestions and nomenclatural advice, especially for the information about the holotype of Prostoma ohmiense (see Appendix). This study was partially supported by the Scandinavia-Japan Sasakawa Foundation (No. 08-19), Showa Seitoku Memorial Foundation (FY2007), Research Institute of Marine Invertebrates (FY2008, No.14), and Grant-in-Aid for Young Scientists (B) (No. 20770061).

\section{Appendix: Holotype of Prostoma ohmiense}

The holotype of Prostoma ohmiense Chernyshev, Timoshkin and Kawakatsu, 1998 is possibly LBM 1340000037 . Chernyshev et al. (1998) identified the holotype by the numbers TS No. 4 and KSL No. 2260. It is uncertain whether LBM 1340000037 is truly the holotype. Among four slides that were delivered by O. A. Timoshkin to the Lake Biwa Museum for deposition in 1998, a slide marked by Chernyshev as holotype with a registration number is not No. 2260 , but No. 2259 b-1, and none was labeled as No. 2260. Furthermore, according to the description the holotype is supposed to consist of sagittal sections of the anterior part of the body and transverse sections of the remainder, but No. 2259 b-1 has sections in only one plane. Efforts in 2003 to resolve this matter among the authors of Chernyshev et al. (1998) failed. In correspondence with M. J. Grygier at the Lake Biwa Museum, Timoshkin has been able to cite his original collection records in detail, but while Chernyshev was confident that LBM 1340000037 is indeed No. 2260 and the real holotype, Kawakatsu disagreed, considering this slide to be part of Paratype No. 2. Earlier, however, in a letter of 1 June 1998 to Timoshkin and Chernyshev, Kawakatsu had referred to Timoshkin's specimen No. 4 from off Shin-Asahi-chô in Lake Biwa, i.e., the specimen named as holotype in the published paper, as "KSL No. 2259-b; transverse sections". Perhaps the true holotype (or part of it) remains in Russia or has been lost, but in light of this letter, it seems more likely that LBM 1340000037 is the actual intended holotype but confusion arose about slide numbers and planes of sectioning during the production of the published description. Timoshkin's notes state that the specimen collected from off Shin-Asahi-chô was very bent, and the specimen on the slide is indeed bent in three places, with four cuts of different parts of the body being visible in many sections. 


\section{References}

Anadon, N. and Bitar, G. 1992. On the anatomy of Oerstedia vittata Hubrecht, 1879 (Nemertea, Enopla, Monostiliferoidea) from the Moroccan coasts. Bulletin de la Société Zoologique de France 117: 383-391.

Antipa, G. 1941. Marea Neagră. Vol. I. Oceanografia, Bionomia şi Biologia Generală a Mării Negre. Publicatiunile Fondului Vasile Adamachi 10: 1-313.

Barry, R. K. (Ed.) 1997. ALA-LC Romanization Tables: Transliteration Schemes for NonRoman Scripts, Approved by the Library of Congress and the American Library Association. Cataloging Distribution Service, Library of Congress, Washington, D.C., 239 pp.

Berg, G. 1985. Studies on Nipponnemertes Friedrich (Nemertini, Hoplonemertini). II. Taxonomy of Nipponnemertes pulcher (Johnston) and some other species. Zoologica Scripta 14: 239-246.

Berg, G. and Gibson, R. 1996. A redescription of Nemertoscolex parasiticus Greeff, 1879, an apparently endoparasitic heteronemertean from the coelomic fluid of the echiuroid Echiurus echiurus (Pallas). Journal of Natural History 30: 163-173.

Bürger, O. 1904. Nemertini. Das Tierreich 20: 1-151.

Cantell, C.-E. 1996. Redescription of Leucocephalonemertes aurantiaca (Grube, 1855) (Nemertini) n. gen. from the Mediterranean. Ophelia 45: 115-125.

Cantell, C.-E. 1998. The anatomy and taxonomy of Amorphonemertes kubergensis gen. et sp. nov. (Nemertini) from the Tromsø area (Norway). Sarsia 83: 293-300.

Cantell, C.-E. 2001. On the anatomy and taxonomy of Tubulanus lutescens $\mathrm{n}$. sp. (Nemertini) from the west coast of Sweden. Ophelia 54: 213-221.

Cantell, C.-E. 2005. On the anatomy and taxonomy of Oxypolella (Nemertini) and further notes on Oxypolella bergendali Cantell, 1975. Journal of Natural History 39: 123-132.

Chernyshev, A. V. 1991. Tetrastemma commensalis and Asteronemertes gibsoni gen. et sp. n. (Hoplonemertini, Tetrastemmidae) commensals of starfish. Zoologicheskiy Zhurnal 70: 34-39. [In Russian with English abstract]

Chernyshev, A. V. 1992. On the names of some nemertines. Zoologicheskiy Zhurnal 71: 134-136. [In Russian with English abstract]

Chernyshev, A. V. 1995. On the higher taxa of the phylum Nemertea with the taxonomic review of the subclass Anopla. Zoologicheskiy Zhurnal 74: 7-18. [In Russian with English abstract]

Chernyshev, A. V. 1998a. New monostiliferous nemerteans (Enopla, Monostilifera) from the Sea of Japan. Zoologicheskiy Zhurnal 77: 397-403. [In Russian with English abstract]

Chernyshev, A. V. 1998b. On the genus Gurjanovella Uschakov, 1926 (Nemertea: Enopla). Zoosystematica Rossica 7: 9-11.

Chernyshev, A. V. 1998c. New data on interstitial nemerteans of the family Ototyphlonemertidae (Enopla, Monostilifera) from the Sea of Japan. Zoologicheskiy Zhurnal 77: 266-269. [In Russian with English abstract]

Chernyshev, A. V. 1998d. Nemerteans of the genus Tetrastemma (Enopla, Monostilifera) from the Far East seas of Russia. Zoologicheskiy Zhurnal 77: 995-1002. [In Russian with English abstract]

Chernyshev, A. V. 1999a. Nemerteans of the genus Antarctonemertes (Enopla, Monostilifera). Zoologicheskiy Zhurnal 78: 939-948. [In Russian with English abstract]

Chernyshev, A. V. 1999b. Nemertines of the family Carinomidae (Nemertea, Anopla). 1. Description of Carinoma uschakovi sp. n. and Statolitonemertes sachalinica Korotkevitsch. Zoologicheskiy Zhurnal 78: 1275-1283. [In Russian with English abstract]

Chernyshev, A. V. 2002a. Description of a new species of the genus Poseidonemertes (Ne- 
mertea, Monostilifera) with establishment of the family Poseidonemertidae. Zoologicheskiy Zhurnal 81: 909-916. [In Russian with English abstract]

Chernyshev, A. V. 2002b. A new nemertean, Callinera zhirmunskyi sp. n., from the Pacific coast of Canada with a special reference to Callineridae taxonomy. Biologiia Moria 28: 143-146. [English translation available in Russian Journal of Marine Biology 28: 132-135.]

Chernyshev, A. V. 2003a. A new species of the genus Hubrechtella (Nemertea, Anopla) from the Sea of Japan and establishment of the family Hubrechtellidae. Biologiia Moria 29: 368-370. [In Russian with English abstract]

Chernyshev, A. V. 2003b. Ototyphlonemertes valentinae sp. n. (Enopla, Ototyphlonemertidae) is an interstitial nemertean from the Sea of Japan. Zoologicheskiy Zhurnal 82: 868-871. [In Russian with English abstract]

Chernyshev, A. V. 2003c. A new species of Tetrastemma from the Sea of Japan and redescription of Tetrastemma laminariae Uschakov, 1928 (Nemertea: Tetrastemmatidae). Zoosystematica Rossica 12: 19-22.

Chernyshev, A. V. 2004a. Two new genera of nemertean worms of the family Tetrastemmatidae (Nemertea: Monostilifera). Zoosystematica Rossica 12: 151-156.

Chernyshev, A. V. 2004b. Problems of taxonomy of the "Lineus ruber" heteronemertean complex (Nemertea, Anopla). Zoologicheskiy Zhurnal 83: 788-794. [In Russian with English abstract]

Chernyshev, A. V. 2007. Nemerteans of the genus Ototyphlonemertes (Enopla: Ototyphlonemertidae) from Van Phong Bay (southern Vietnam). Biologiia Moria 33: 232-235 [In Russian with English abstract]

Chernyshev, A. V. and Chaban, E. M. 2005. Types of the pelagic nemerteans in the Zoological Institute, St. Petersburg (Nemertea: Enopla). Zoosystematica Rossica 13: 151-156.

Chernyshev, A. V., Timoshkin, O. A. and Kawakatsu, M. 1998. Prostoma ohmiense sp. nov., a new species of freshwater nemertean from Lake Biwa-Ko, central Japan, with special reference to the taxonomy and distribution of the known species in the genus Prostoma Dugès, 1828 (Enopla, Hoplonemertea, Monostylifera, Tetrastemmatidae). Bulletin of Fuji Women's College, Series II 36: 51-66.

Coe, W. R. 1905. Nemerteans of the west and northwest coasts of America. Bulletin of the Museum of Comparative Zoölogy at Harvard College 47: 1-318.

Coe, W. R. 1940. Revision of the nemertean fauna of the Pacific coasts of North, Central, and northern South America. Allan Hancock Pacific Expeditions 2: 247-322.

Coe, W. R. 1943. Biology of the nemerteans of the Atlantic coast of North America. Transactions of the Connecticut Academy of Arts and Sciences 35: 129-328.

Crandall, F. B. 1993. The genus Valdivianemertes Stiasny-Wijnhoff 1923 (Nemertea, Enopla, Hoplonemertea): nomenclatural status and proper systematic position. Hydrobiologia 266: $175-184$.

Crandall, F. B. 1994. Valdivianemertes Stiasny-Wijnhoff, 1923 (Nemertea): proposed conservation. Bulletin of Zoological Nomenclature 51: 298-301.

Crandall, F. B. and Gibson, R. 1998. A second genus of pelagic Cratenemertidae (Nemertea, Hoplonemertea). Hydrobiologia 365: 173-198.

Crandall, F. B. and Norenburg, J. L. 1999. Checklist of the Nemertean Fauna of the United States. Smithsonian Institution, Washington, D.C., 36 pp.

Crandall, F. B., Norenburg, J. L., Chernyshev, A. V., Maslakova, S., Schwartz, M. and Kajihara, H. 2002. Checklist of the Nemertean Fauna of Japan and Northeastern Asia. Smithsonian Institution, Washington, D.C., 44 pp. [PDF available from http://nemertes.si.edu/ PDFs/epub2917.pdf]

Duchassaing, P. and Michelotti, J. 1860. Mémoire sur les coralliaires des Antilles. Memorie 
della Reale Accademia delle Scienze di Torino, Serie Seconda 19: 56-87.

Envall, M. 1996. Ototyphlonemertes correae sp. nov. and a redescription of O. duplex (Nemertea: Monostilifera: Ototyphlonemertidae), with a phylogenetic consideration of the genus. Journal of Zoology 238: 253-277.

Envall, M and Sundberg, P. 1993. Intraspecific variation in nemerteans (Nemertea): synonymization of the genera Paroerstedia and Oerstediella with Oerstedia. Journal of Zoology 230: 293-318.

Friedrich, H. 1957. Beiträge zur Kenntnis der arktischen Hoplonemertinen. Videnskabelige Meddelelser fra Dansk Naturhistorisk Forening i Kjøbenhavn 119: 129-154.

Frutos, I., Montalvo, S. and Junoy, J. 1998. A new species of Prosorhochmus (Hoplonemertea, Monostilifera) from the Chafarinas Islands (western Mediterranean). Journal of Zoology 245: 293-298.

Gibson, R. 1979. Nemerteans of the Great Barrier Reef. 2. Anopla Heteronemertea (Baseodiscidae). Zoological Journal of the Linnean Society 66: 137-180.

Gibson, R. 1981. Nemerteans of the Great Barrier Reef. 3. Anopla Heteronemertea (Lineidae). Zoological Journal of the Linnean Society 71: 171-235.

Gibson, R. 1982a. British Nemerteans. Cambridge University Press, Cambridge, vi+212 pp.

Gibson, R. 1982b. Nemertea. Pp. 823-846. In: Parker, S. P. (Ed.) Synopsis and Classification of Living Organisms, Vol. 1. McGraw-Hill, New York.

Gibson, R. 1983. Nemerteans of the Great Barrier Reef. 6. Enopla Hoplonemertea (Polystilifera: Reptantia). Zoological Journal of the Linnean Society 78: 73-104.

Gibson, R. 1988. A new species of marine nemertean from Anglesey, North Wales, with a discussion of the genus Paroerstedia Friedrich, 1955. Journal of Natural History 22: 733-745.

Gibson, R. 1994. Nemerteans. Field Studies Council, Shrewsbury, vii+224 pp.

Gibson, R. 1995. Nemertean genera and species of the world: an annotated checklist of original names and description citations, synonyms, current taxonomic status, habitats and recorded zoogeographic distribution. Journal of Natural History 29: 271-562.

Gibson, R. 1997. New benthic nemerteans from Hong Kong. Pp. 9-29. In: Morton, B. (Ed.) The Marine Flora and Fauna of Hong Kong and Southern China, Vol. 4. Hong Kong University Press, Hong Kong.

Gibson, R. 1999. Further studies on the nemertean fauna of Rottnest Island, Western Australia. Pp. 359-376. In: Walker, D. I. and Wells, F. E. (Eds) The Seagrass Flora and Fauna of Rottnest Island, Western Australia. Western Australian Museum, Perth.

Gibson, R. 2002. The Invertebrate Fauna of New Zealand: Nemertea (Ribbon Worms). National Institute of Water and Atmospheric Research, Wellington, $87 \mathrm{pp}$.

Gibson, R. and Crandall, F. B. 1989. The genus Amphiporus Ehrenberg (Nemertea, Enopla, Monostilifera). Zoologica Scripta 18: 453-470.

Gibson, R. and Moore, J. 1998. Further observations on the genus Geonemertes with a description of a new species from the Philippine Islands. Hydrobiologia 365: 157-171.

Gibson, R. and Strand, M. 2002. A new genus and species of monostiliferous hoplonemertean (Enopla: Hoplonemertea: Monostilifera) from New Zealand. Zootaxa 50: 1-20.

Gibson, R. and Sundberg, P. 1999. Six new species of palaeonemerteans (Nemertea) from Hong Kong. Zoological Journal of the Linnean Society 125: 151-196.

Gibson, R. and Sundberg, P. 2001. Some nemerteans (Nemertea) from Queensland and the Great Barrier Reef, Australia. Zoologica Scripta 18: 1259-1273.

Gibson, R. and Sundberg, P. 2002. Some heteronemerteans (Nemertea) from the Solomon Islands. Journal of Natural History 36: 1785-1804.

Gibson, R. and Wang, H. 2002. A new genus and species of freshwater monostiliferous hoplonemertean (Nemertea, Enopla) from the People's Republic of China. Hydrobiologia 
489: 185-196.

Gontcharoff, M. 1951. Biologie de la régénération et de la reproduction chez quelques Lineidae de France. Annales des Sciences Naturelles, Zoologie, Série 11 13: 149-235.

Greef, R. 1879. Die Echiuren (Gephyrea armata). Nova Acta Academiae Caesareae Leopoldino-Carolinae Germanicae Naturae Curiosorum (Verhandlungen der Kaiserlichen Leopoldinisch-Carolinischen Deutschen Akademie der Naturforscher) 41: 1-172.

Grube, E. 1855. Bemerkungen über einige Helminthen und Meerwürmer. Archiv für Naturgeschichte 1: 137-158.

Härlin, M. 1998. Tree-thinking and nemertean systematics, with a systematization of the Eureptantia. Hydrobiologia 365: 33-46.

Härlin, M. and Härlin, C. 2001. Phylogeny of the eureptantic nemerteans revisited. Zoologica Scripta 30: 49-58.

Härlin, M. and Sundberg, P. 1995. Cladistic analysis of the eureptantic nemerteans (Nemertea: Hoplonemertea). Invertebrate Taxonomy 9: 1211-1229.

Hochberg, F. G. and Lunianski, D. N. 1998. Nemertean collections at the Santa Barbara Museum of Natural History: type specimens and vouchers for Wesley R. Coe's 1940 publication. Hydrobiologia 365: 291-300.

Hubrecht, A. A. W. 1879. The genera of European nemerteans critically revised, with description of several new species. Notes from the Leyden Museum 1: 193-232.

International Commission on Zoological Nomenclature. 1999. International Code of Zoological Nomenclature, Fourth Edition. International Trust for Zoological Nomenclature, London, xxix+306 pp.

International Commission on Zoological Nomenclature. 2003. Opinion 2888 Valdivianemertes Stiasny-Wijnhoff, 1923 (Nemertea): not conserved. Bulletin of Zoological Nomenclature 60: $59-60$

International Commission on Zoological Nomenclature. 2007. Official Lists and Indexes of Names in Zoology. International Trust for Zoological Nomenclature, London, 882 pp. [PDF available from http://www.iczn.org/lists\&indexes.pdf]

Ivanov, V. A., Bigatti, G., Penchaszadeh, P. E. and Norenburg, J. L. 2002. Malacobdella arrokeana (Nemertea: Bdellonemertea), a new species of nemertean from the southwestern Atlantic Ocean entocommensal in Panopea abbreviata (Bivalvia, Heterodonta, Hiatellidae) in Argentina. Proceedings of the Biological Society of Washington 115: 359-367.

Iwata, F. 1998. On the hoplonemertean, Kameginemertes parmiornatus (Iwata, 1957) gen. n., comb. n. from Sagami Bay, Japan. Hydrobiologia 365: 199-213.

Iwata, F. 2001. Nipponnemertes fernaldi, a new species of swimming monostiliferous hoplonemertean from the San Juan Archipelago, Washington, U.S.A. Proceedings of the Biological Society of Washington 114: 833-857.

Iwata, F. 2006. On four monostiliferous hoplonemerteans, including three new genera and species from Washington State and British Columbia. Journal of Natural History 40: 873-913.

Iwata, F. 2007. Cyanonemertes elegans, new genus, new species, a marine hoplonemertean from Washington State, U.S.A. Proceedings of the Biological Society of Washington 120: 197-213.

Jensen, K. and Sadeghian, P. S. 2005. Nemertea (ribbon worms). Pp. 205-210. In: Rohde, K. (Ed.) Marine Parasitology. CSIRO Publishing, Collingwood and CABI Publishing, Wallingford.

Kajihara, H. 2002. Two new species of Zygonemertes (Nemertea: Enopla: Monostilifera) from Hokkaido, Japan. Species Diversity 7: 121-143.

Kajihara, H. 2006. Four palaeonemerteans (Nemertea: Anopla) from a tidal flat in middle 
Honshu, Japan. Zootaxa 1163: 1-47.

Kajihara, H. 2007a. Callinera emiliae sp. nov. (Nemertea: Palaeonemertea) from Negros Island, the Philippines. Zootaxa 1454: 39-47.

Kajihara, H. 2007b. Two species of Nemertopsis (Nemertea: Hoplonemertea: Monostilifera) living in association with Capitulum mitella (Crustacea: Cirripedia: Thoracica: Lepadomorpha). Zootaxa 1446: 43-58.

Kajihara, H. 2007c. Ototyphlonemertes dolichobasis sp. nov. (Nemertea: Hoplonemertea: Monostilifera: Ototyphlonemertidae), a new species of interstitial nemertean from Japan. Species Diversity 12: 57-66.

Kajihara, H. 2007d. A taxonomic catalogue of Japanese nemerteans (phylum Nemertea). Zoological Science 24: 287-326.

Kajihara, H., Gibson, R. and Mawatari, S. F. 2000. Redescription and taxonomic reassessment of Nemertellina minuta Friedrich, 1935, sensu Yamaoka, 1940 (Nemertea, Hoplonemertea, Monostilifera). Zoological Science 17: 265-276.

Kajihara, H., Gibson, R. and Mawatari, S. F. 2001. A new genus and species of monostiliferous hoplonemertean (Nemertea: Enopla: Monostilifera) from Japan. Hydrobiologia 456: 187-198.

Kajihara, H., Gibson, R. and Mawatari, S. F. 2003. Potamostoma shizunaiense gen. et sp. nov. (Nemertea: Hoplonemertea: Monostilifera): a new brackish-water nemertean from Japan. Zoological Science 20: 491-500.

Keilin, D. 1920. On two new gregarines, Allantocystis dasyhelei n.g., n.sp., and Dendrorhynchus systeni n.g., n.sp., parasitic in the alimentary canal of the dipterous larvae, Dasyhelea obscura Winn. and Systenus sp. Parasitology 12: 154-158.

Kirsteuer, E. 1973. A new polystiliferous hoplonemertean, Curranemertes natans gen. et sp. n., from the Caribbean Sea (Nemertina, Polystilifera Reptantia). Zoologica Scripta 2: 125-140.

Korotkevich, V. S. 1982. [Nemerteans from Chupa Inlet of the White Sea]. Pp. 42-43. In: Scarlato, O. A. (Ed.) Uvelichenie Produktivnosti i Ratzional'nogo Ispol'zovaniya Biologicheskikh Resursov Belogo Moray. Materialy Pervoi Koordinatzionnoi Konferentzii [Increase of the Biological Production and Resources Conservation of the White Sea. Proceedings of the First Coordinating Conference]. Zoological Institute, Leningrad.

Korotneff, A. 1901. Faunistische Studien am Baikalsee. Biologisches Zentralblatt 21: 305-311.

Kyao, N. N. 1954. [A new species of nemertean, Amphiporus commensalus n. sp. from the ambilical grooves of the sea-star Crossaster papposus L.]. Uchenye Zapiski Leningradskogo Ordena Lenina Gosudarstvennogo Universiteta Imeni A. A. Zhdanova, Seriia Biologicheskikh Nauk 35: 135-139.

Leidy, J. 1851. Description of new genera of Vermes. Proceedings of the Academy of Natural Sciences of Philadelphia 5: 239-244.

Maslakova, S. A. and Norenburg, J. L. 2001. Phylogenetic study of pelagic nemerteans (Pelagica, Polystilifera). Hydrobiologia 456: 111-132.

Maslakova, S. A., Thiel, M., Vásquez, N. and Norenburg, J. L. 2005. The smile of Amphiporus nelsoni Sanchez, 1973 (Nemertea: Hoplonemertea: Monostilifera: Amphiporidae) leads to a redescription and a change in family. Proceedings of the Biological Society of Washington 118: $483-498$.

McIntosh, W. C. 1867. On the annelids of St. Andrews. Report of the Meetings of the British Association for the Advancement of Science 37: 92-93.

McIntosh, W. C. 1873-1874. A Monograph of the British Annelids. Part I. The Nemerteans. Ray Society, London, v+214 pp., 23 pls. [Pp. 1-96, pls 1-10 in 1873; pp. 97-214, pls 11-23 in 1874]

Moretto, H. J. A. 1998. A new heteronemertean from the Argentine coast of the southern At- 
lantic. Hydrobiologia 365: 215-222.

Örsted, A. S. 1844. Entwurf einer systematischen Eintheilung und speciellen Beschreibung der Plattwürmer, auf microscopische Untersuchungen. Reitzel, C. A., Copenhagen, viii +96 pp., 3 pls.

Punnett, R. C. 1900. On some South Pacific nemertines collected by Dr Willey. Zoological Results Based on Material from New Britain, New Guinea, Loyalty Islands and Elsewhere, Collected during the Years 1895, 1896 and 1897 by Arthur Willey 5: 569-584.

Punnett, R. C. 1903. Nemerteans. Pp. 101-118. In: Gardiner, J. S. (Ed.) The Fauna and Geography of the Maldive and Laccadive Archipelagos. Cambridge University Press, Cambridge.

Rathke, H. 1843. Beiträge zur Fauna Norwegens. Verhandlungen der Kaiserlichen Leopoldinisch-Carolinischen Akademie der Naturforscher 20: 1-264.

Rathke, J. 1799. Jagttagelser henhørende til Indvoldeormenes og Bløddyrenes Naturhistorie. Skrivter af Naturhistorie Selskabet, Kjøbenhavn 5: 61-148.

Riser, N. W. 1988. Arhynchonemertes axi gen. n., sp. n. (Nemertinea)-an insight into basic acoelomate bilaterian organology. Progress in Zoology 36: 367-373.

Riser, N. W. 1994. The morphology and generic relationships of some fissiparous heteronemertines. Proceedings of the Biological Society of Washington 107: 548-556.

Riser, N. W. 1998a. The morphology of Micrura leidyi (Verrill, 1892) with consequent systematic revaluation. Hydrobiologia 365: 149-156.

Riser, N. W. 1998b. New Zealand nemertines from kelp holdfasts: Hoplonemertinea 1. Nipponnemertes sanguinea sp. n. New Zealand Journal of Zoology 25: 287-294.

Ritger, R. K. and Norenburg, J. L. 2006. Tubulanus riceae new species (Nemertea: Anopla: Palaeonemertea: Tubulanidae), from South Florida, Belize and Panama. Journal of Natural History 40: 931-942.

Rogers, A. D., Gibson, R. and Tunnicliffe, V. 1996. A new genus and species of monostiliferous hoplonemertean colonizing an inchoate hydrothermal field on Juan de Fuca Ridge. DeepSea Research, Part I, Oceanographic Research Papers 43: 1581-1599.

Santos, C., Norenburg, J. L. and Bueno, S. L. S. 2006. Three new species of Carcinonemertes (Nemertea, Carcinonemertidae) from the southeastern coast of Brazil. Journal of Natural History 40: 915-930.

Schmarda, L. K. 1859. Neue Turbellarien, Rotatorien und Anneliden beobachtet und gesammelt auf einer Reise um die Erde 1853 bis 1857, Part 1. Engelmann, W., Leipzig, 66 pp.

Schwartz, M. L. and Norenburg, J. L. 2005. Three new species of Micrura (Nemertea: Heteronemertea) and a new type of heteronemertean larva from the Caribbean Sea. Caribbean Journal of Science 41: 528-543.

Senz; W. 1994. Cerebratulus knerii (Diesing, 1850) a junior synonym of Notospermus geniculatus (Delle Chiaje, 1828) (Nemertini: Heteronemertini) and an additional note on the anatomy of its brain. Zoologischer Anzeiger 233: 241-245.

Senz, W. 1995. Lineus rovinjensis nom. n. (olim Lineus arenicolus Senz, 1993) and Tetrastemma kirsteueri nom. n. (olim Tetrastemma cruciatus Senz, 1993) (Nemertinea: Heteronemertinea, Hoplonemertinea). Annalen des Naturhistorischen Museums in Wien 97B: 55-56.

Senz, W. 1996a. Eine Untersuchung der Probleme der Heteronemertinen-Systematik, dargestellt anhand von Lineus bergendali n. sp., einer neuen Heteronemertine aus dem Golf von Triest (Nemertini: Anopla: Lineidae). Senckenbergiana Biologica 76: 197-208.

Senz, W. 1996b. Über die Gattung Valencinura Bergendal, 1902 (Heteronemertini: Nemertini) - nebst Überlegungen zur Bedeutung der phylogenetischen Systematik für die gegenwärtige Klassifikation der Nemertinen. Sitzungsberichte und Anzeiger, Österreichische Akademie der Wissenschaften, Mathematisch-Naturwissenschaftliche Klasse, Abteilung I, Biologische Wissenschaften und Erdwissenschaften 203: 29-49. 
Senz, W. 1996c. On the genus Minutanemertes Senz, 1993 (Nemertini: Hoplonemertini). Annalen des Naturhistorischen Museums in Wien 98B: 45-55.

Senz, W. 1996d. Prostoma communopore sp. n., eine neue Nemertine aus dem Grundwasser in Österreich (Nemertini: Hoplonemertini: Monostilifera). Annalen des Naturhistorischen Museums in Wien 98B: 23-30.

Senz, W. 1996e. Wiederbeschreibung und taxonomische Diskussion von Borlasia trilineata Schmarda, 1859. Annalen des Naturhistorischen Museums in Wien 98B: 31-43.

Senz, W. 1997a. Morphologie und klassifikatorische Position einiger anopler Nemertinen (Nemertini: Anopla). Annalen des Naturhistorischen Museums in Wien 99B: 423-496.

Senz, W. 1997b. Redescription and systematic discussion of Amphiporus heterophthalmus (Schmarda, 1859). Spixiana 20: 193-198.

Senz, W. 1997c. Über die phylogenetische Herkunft und systematische Stellung der Gattung Malacobdella Blainville, 1827 (Nemertini, Bdellonemertini). Sitzungsberichte und Anzeiger, Österreichische Akademie der Wissenschaften, Mathematisch-Naturwissenschaftliche Klasse, Abteilung I, Biologische Wissenschaften und Erdwissenschaften 204: 39-62.

Senz, W. 2000. Neue Nemertinen aus dem Golf von Arabien. 1. Palaeonemertini. Annalen des Naturhistorischen Museums in Wien 102B: 321-373.

Senz, W. 2001a. Neue Nemertinen aus dem Golf von Arabien. 2. Heteronemertini und monostilifere Hoplonemertini. Annalen des Naturhistorischen Museums in Wien 103B: 13-75.

Senz, W. 2001b. Eine neue Heteronemertine von der Küste Japans (Nemertini). Spixiana 24: 5-12.

Shields, J. D. 2001. Ovicides julieae n. gen., n. sp. (Nemertea: Carcinonemertidae) on xanthid crabs from the Great Barrier Reef, Australia. Journal of Crustacean Biology 21: 304-312.

Stiasny-Wijnhoff, G. 1934. Some remarks on North Atlantic non-pelagic Polystylifera. Quarterly Journal of Microscopical Science 77: 167-190.

Stiasny-Wijnhoff, G. 1936. Die Polystilifera der Siboga-Expedition. Siboga Expeditie 22: 1-214.

Strand, M., Hjelmgren, A. and Sundberg, P. 2005. Genus Baseodiscus (Nemertea: Heteronemertea): molecular identification of a new species in a phylogenetic context. Journal of Natural History 39: 3785-3793.

Sun, S.-C. 1993. A new monostiliferous hoplonemertean: Pseudotetrastemma qingdaoensis gen. nov. sp. nov. Pp. 1035-1045. In: Shandong Association for Science and Technology (Ed.) Advance in Natural Sciences of Shandong. Scientific and Technical Press of China, Beijing.

Sun, S.-C. 1995a. Nemerteans of Zhoushan Islands, East China Sea coast, China II. Enopla: Distromatorhynchocoela: Monostilifera: Tetrastemmidae. Chinese Journal of Oceanology and Limnology 13: 278-283.

Sun, S.-C. 1995b. Nemerteans of Zhoushan Islands, East China Sea coast, China I. Enopla: Distromatorhynchocoela: Monostilifera: Emplectonemertidae. Chinese Journal of Oceanology and Limnology 13: 162-168.

Sun, S.-C. 2001. A new mangrove-dwelling nemertean from China. Hydrobiologia 456: 199-209.

Sun, S.-C. 2006. On nemerteans with a branched proboscis from Zhanjiang, China. Journal of Natural History 40: 943-965.

Sun, S.-C. and Dong, S.-L. 1998. Redescription and taxonomic reconsideration of Nemertopsis gracilis var. bullocki Coe, 1940. Chinese Journal of Oceanology and Limnology 16: 271-279.

Sun, S.-C, Dong, S.-L. and Chen, Y.-H. 1998. A new monostiliferous hoplonemertean from the East China Sea. Ophelia 49: 17-28.

Sun, S.-C. and Lu, J.-R. 1998. A new genus and species of heteronemertean from the 
Changjiang (Yangtze) River estuary. Hydrobiologia 367: 175-187.

Sun, S.-C. and Lu, J.-R. 2008. Yininemertes nom. nov. for preoccupied Yinia Sun and Lu, 1998 (Nemertea: Heteronemertea). Species Diversity 13: 187-188.

Sun, S.-C. and Yin, Z.-F. 1995. Freshwater nemertean: a new subspecies of genus Prostoma. Acta Hydrobiologica Sinica 19: 135-138. [In Chinese with English abstract]

Sundberg, P. 1991. A proposal for renaming the higher taxonomic categories in the phylum Nemertea. Journal of Natural History 25: 45-48.

Sundberg, P. and Andersson, S. 1995. Random amplified polymorphic DNA (RAPD) and intraspecific variation in Oerstedia dorsalis (Hoplonemertea, Nemertea). Journal of the Marine Biological Association of the United Kingdom 75: 483-490.

Sundberg, P. and Gibson, R. 1995. The nemerteans (Nemertea) of Rottnest Island, Western Australia. Zoologica Scripta 24: 101-141.

Sundberg, P., Gibson, R. and Olsson, U. 2003. Phylogenetic analysis of a group of palaeonemerteans (Nemertea) including two new species from Queensland and the Great Barrier Reef, Australia. Zoologica Scripta 32: 279-296.

Sundberg, P., Gibson, R. and Strand, M. 2007. Swedish nemerteans (phylum Nemertea), with description of a new hoplonemertean genus and species. Journal of Natural History 41: $2287-2299$.

Takakura, U. 1898. [A classification of the nemerteans of the Misaki region]. Zoological Magazine, Tokyo 10: 38-44, 116-120, 184-187, 331-337, 424 429. [In Japanese]

Thollesson, M. and Norenburg, J. L. 2003. Ribbon worm relationships: a phylogeny of the phylum Nemertea. Proceedings of the Royal Society of London, B 270: 407-414.

Timofeev, T. 1913. Cerebratulus kowalewskii. P. 214. In: Zernov, S. A. K Voprosu ob Izuchenii Zhyzni Chernogo Morya [On the Question Concerning Investigations of the Life of the Black Sea]. Zapiski Akademii Nauk, Series 8, 32: 1-299. [In Russian]

Uschakov, P. V. 1926. Zur Fauna der Nemertinen des Weissen Meeres. Issledovaniia Russkikh Moreǐ 3: 47-71. [In Russian with German abstract]

Uschakov, P. V. 1928. Beschreibung einiger neuen Nemertinenarten vom Barents-Meere, Weißen Meere und Nowaja-Semlja. Zoologische Jahrbücher, Abteilung für Systematik, Ökologie und Geographie der Tiere 54: 407-424.

Vernet, G. 1997. Myoisophagos bicolor, sp. nov., nouvelle némerte anopla (Lineidae) récoltée en Manche (Gatteville, France). Bulletin de la Société Zoologique de France 122: 149-154.

Verrill, A. E. 1892. The marine nemerteans of New England and adjacent waters. Transactions of the Connecticut Academy of Arts and Sciences 8: 382-456.

Wern, J. O. 1998. An enigmatic heteronemertean from the Gulf of Mexico. Hydrobiologia 365: 135-147.

Wheeler, J. F. G. 1934. Nemerteans from the South Atlantic and southern oceans. Discovery Reports 9: 215-294.

Wijnhoff, G. 1913. Die Gattung Cephalothrix und ihre Bedeutung für die Systematik der Nemertinen. II. Systematischer Teil. Zoologische Jahrbücher, Abteilung für Systematik, Ökologie und Geographie der Tiere 34: 291-320.

Yamaoka, T. 1940. The fauna of Akkeshi Bay. IX. Nemertini. Journal of the Faculty of Science, Hokkaido Imperial University, Series 6, Zoology 7: 205-263. 